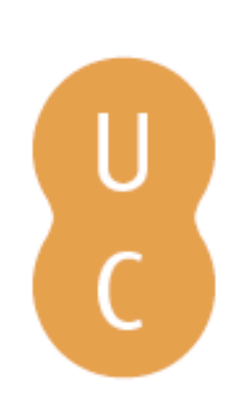

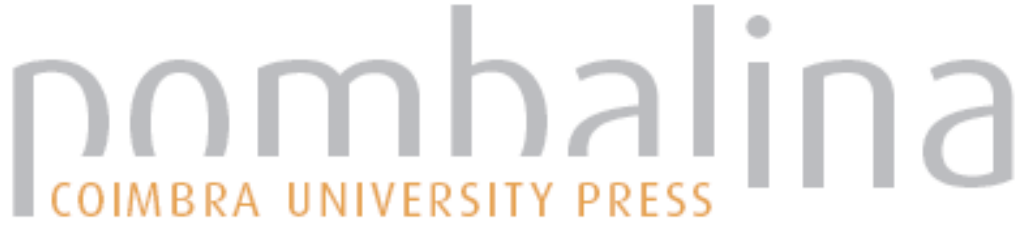

\section{A hurritização das conceções mitológicas de poder no império hitita}

\author{
Autor(es): Galhano, João Paulo
}

Publicado por: Imprensa da Universidade de Coimbra

URL

persistente: URI:http://hdl.handle.net/10316.2/45215

DOI: $\quad$ DOl:https://doi.org/10.14195/978-989-26-1626-1_6

Accessed : $\quad$ 26-Apr-2023 11:00:43

A navegação consulta e descarregamento dos títulos inseridos nas Bibliotecas Digitais UC Digitalis, UC Pombalina e UC Impactum, pressupõem a aceitação plena e sem reservas dos Termos e Condições de Uso destas Bibliotecas Digitais, disponíveis em https://digitalis.uc.pt/pt-pt/termos.

Conforme exposto nos referidos Termos e Condições de Uso, o descarregamento de títulos de acesso restrito requer uma licença válida de autorização devendo o utilizador aceder ao(s) documento(s) a partir de um endereço de IP da instituição detentora da supramencionada licença.

Ao utilizador é apenas permitido o descarregamento para uso pessoal, pelo que o emprego do(s) título(s) descarregado(s) para outro fim, designadamente comercial, carece de autorização do respetivo autor ou editor da obra.

Na medida em que todas as obras da UC Digitalis se encontram protegidas pelo Código do Direito de Autor e Direitos Conexos e demais legislação aplicável, toda a cópia, parcial ou total, deste documento, nos casos em que é legalmente admitida, deverá conter ou fazer-se acompanhar por este aviso.

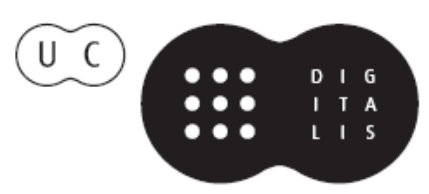




\section{Arqueologias de Império}

\section{Delfim Leão, José Augusto Ramos, Nuno Simões Rodrigues (coords.)}

IMPRENSA DA UNIVERSIDADE DE COIMBRA 


\title{
A hurRitizaÇão das CONCEÇões MitológiCAS DE PODER NO IMPÉRIO HITITA ${ }^{1}$ \\ (The hurritisation of mythological concepts of power in the Hittite Empire)
}

\author{
João Paulo Galhano \\ (jptsgalhano@gmail.com; ORCID: 0000-0003-4934-2696) \\ Universidade de Lisboa, Faculdade de Letras, Centro de História \\ «Assim disse Hupašiya a Inara: \\ 'Se me deito contigo, irei e cumprirei o desejo do teu coração.' \\ E ele deitou-se com ela.»²
}

\begin{abstract}
Resumo - No presente estudo pesquisámos os processos de hurritização dos conteúdos mitológicos hititas. Após análise da hurritização étnica do território da Anatólia, verificámos que, nos mitos de divindades ausentes, subsistem conceções de interdependência e correlação dos entes divinos, a par de uma tendência não hierárquica de organização do panteão anatólico antigo. Já o Mito de Illuyanka apresenta uma modalidade mitológica diferente, assente na luta entre um deus e uma força má. As narrativas hurritas trouxeram ao panteão anatólico estruturas que evidenciam ideias de realeza divina, de valorização do horizonte familiar e de diferenciação das instâncias de poder. Os mitos hurritas trouxeram ainda dimensões temporais alargadas e uma encenação literária do poder. O mito O Desaparecimento do Deus Sol parece cruzar elementos conceptuais que se podem encontrar nos mitos de divindades ausentes mas também outros que são típicos da mitologia de origem hurrita.
\end{abstract}

Palavras-Chave: Hititas; Hurritas; mitos; influência.

AвSTRACT - In this research article we looked for the hurrianization processes of the hittite mythological contents. After the analysis of the ethnic hurrianization of the Anatolian territory, we confirmed that, in the myths of disappearing gods, there is an idea of interdependence and correlation of divine agents, as well as a non-hierarchical tendency in the arrangement of the ancient Anatolian pantheon. The Illuyanka Tales show a different mythological mode, based in the fight between a god and an evil power. The Hurrian myths have brought to the Anatolian pantheon some narrative structures that include the idea of divine kingship, of emphasis on the familial order, and of differentiation of the power levels. Besides, the Hurrian myths have included a wide temporal dimension and the literary play-acting of power. The myth of The Disappearance of the Sun God seems to join elements found in the myths of disappearing gods and other ingredients typical of the Hurrian mythology.

KeYwords: Hittites; Hurrians; myths; influence.

\footnotetext{
${ }^{1}$ Este trabalho foi apoiado por Fundos Nacionais através da FCT - Fundação para a Ciência e a Tecnologia no âmbito do projeto UID/HIS/04311/2013.

${ }^{2}$ CTH 321, Mito de Illuyanka, A obv. i 24 e ss.
} 
A história hitita ${ }^{3}$ tem tido uma periodização similar à de outros reinos do Próximo Oriente Antigo (em sentido lato), designadamente o egípcio, dando lugar à divisão em Reino Antigo, Reino Médio e Reino Novo ${ }^{4}$. Alguns preferem simplificar o esquema e reduzir a história hitita a duas fases principais: o Reino Antigo e o Reino Novo, propondo a cisão no início do reinado de Tudhaliya I, ou seja, no final do séc. XV ou início do séc. XIV a.C. ${ }^{5}$ Esta periodização, se reflete uma viragem na orientação política hitita, que a partir de Tudhaliya I está sob o desígnio da conquista de terras longínquas na Síria e no oeste da Anatólia, não dá relevo ao momento de realização imperial conseguido com Šuppiluliuma I, cuja maior concretização aconteceu no domínio da diplomacia e da estratégia militar «internacional», resultando na anexação do reino hurrita do Mitanni e de vastas zonas no norte da Síria.

A cultura religiosa e literária hitita do período imperial ficou marcada por um elevado grau de fusão da matriz autóctone hatiana com os aportes mítico-religiosos hurritas, siríos e mesopotâmicos, situação que derivou dos contactos continuados das populações autóctones com os povos vizinhos do leste e sudeste da Anatólia. Este processo culminaria na integração do Mitanni e do norte da Síria nos domínios hititas, para além dos territórios disputados a sudoeste com o reino de Arzawa. Por essa via, a história cultural hitita ficou superlativamente marcada pela integração de elementos hurritas, a ponto de, no período imperial, a cultura mitológica hurrita ser tão hitita quanto a matriz hatiana originária da Anatólia.

Interessa então perceber o que significou a hurritização dos conteúdos mitológicos hititas no que trata das conceções de poder, com o propósito de compreender o que mudou com a assimilação e adição de estruturas narrativas mitológicas hurritas à matriz hatiana, tenham sido ou não acompanhadas de processos de sincretismo religioso. Para tal, importa começar por convocar os elementos histórico-geográficos que terão possibilitado aquela hurritização,

\footnotetext{
${ }^{3}$ Por Hititas designa-se o que na literatura de expressão inglesa surge denominado «Hittites» e na área alemã «Hethiter». Por Hatianos os povos anatólios indígenas, que viveram na Anatólia antes da chegada dos Indo-Europeus. Sobre a problemática do nome dos povos da Anatólia cf. Galhano 2012, 4-6.

${ }^{4}$ Horst Klengel (1998) distingue três períodos na história hitita: das ältere Reich (até Telipinu), das "mittlere" Reich (de Tahurwaili até Tudhaliya II) e das neue Reich (Großreichszeit) (de Šuppiluliuma I até Šuppiluliuma II). Também Harry Hoffner (2009, xi) distingue três períodos na história hitita: Old Kingdom (de c. 1600 a c. 1400, i.e. até Muwattalli I), Early New Kingdom ("Middle Kingdom") (de Tudhaliya I (II) até Tudhaliya II (III)) e New Kingdom (de Šuppiluliuma I até Šuppiluliuma II).

${ }^{5}$ Trevor Bryce $(2005,6)$ segue esta periodização. Segundo Gary Beckman «[...] there was no coherent Middle Kingdom period of Hittite history, nor an abrupt transition to the Empire. Rather, a single royal family - or perhaps clan - ruled Hatti from start to finish» (Beckman 2007, 110). As datas indicadas no presente texto são todas a.C., razão para se dispensar esta elucidação em referências posteriores.
} 
pelo menos até Tudhaliya IV, quando o império hitita está ainda plenamente vigoroso.

\section{Política e etnicidade}

O local da futura Huattuša aparece com vestígios de ocupação humana pelo menos desde meados do III milénio, a par de outros pequenos reinos da Anatólia central, junto do rio posteriormente conhecido pelos Hititas por Maraššantiya, o Hális dos Gregos. Ainda antes da viragem para o segundo milénio, terão chegado à Anatólia grupos populacionais Luvitas, Palaítas e Nesitas, todos de matriz linguística indo-europeia ${ }^{6}$. Esta primeira incorporação de elementos indo-europeus numa provável matriz autóctone hatiana terá produzido uma primeira amálgama cultural, mais por adição do que por efetiva fusão cultural, dadas as persistências linguísticas não indo-europeias no Hatti dos séculos posteriores. No período do estabelecimento de feitorias assírias na zona leste da Anatólia ${ }^{7}$ nos primeiros séculos do II milénio, nota-se uma forte componente étnica indo-europeia em Kaneš ${ }^{8}$, uma das mais importantes feitorias de comerciantes assírios, porém, nesse mesmo período, poderão ter logo surgido elementos hurritas na Anatólia central9.

A incorporação de populações hurritas na área anatólica, embora resultando inicialmente, muito possivelmente, das viagens de sacerdotes e adivinhos hurritas ${ }^{10}$, teve como causa importante a deportação de tropas derrotadas nos confrontos militares posteriores, tornando a guerra num importante processo de hurritização daquela área. A primeira unificação política do Hatti, protagonizada por Pithana e Anitta em torno de Kaneš, bem como o fim da maior parte das feitorias assírias, poderão ter sido causadas precisamente pela intervenção

${ }^{6}$ Klengel 1998, 20; Bryce 2005, 10-14.

${ }^{7}$ Designa-se «feitorias assírias» o que surge habitualmente denominado «colónias assírias», seguindo uma justa sugestão de Maria de Lurdes Palma no decurso da primeira sessão do colóquio Arqueologias de Império, em 26 de novembro de 2010. Em alemão é usada a designação Handelsniederlassungen (Klengel 1998, 21 ss.).

${ }^{8}$ Klengel 1998, 24: «Erste Hinweise auf die Anwesenheit von Bewohnern mit einer indoeuropäischen Sprache stammen vor allem aus Kaniš, das mit dem in hethitischen Texten bezeugten Neša gleichgesetzt werden darf». Não nos referimos aqui ao aporte hurrita, nem à tese controversa de a língua hurrita poder pertencer à família indo-europeia; Ilse Wegner, por exemplo, designa a língua hurrita e a língua do Urartu, esta aparentada com a primeira, de "isolierten" Sprachen» (cf. Wegner 2007, 35).

${ }^{9}$ Collins 2007, 31-32; Bryce 2005, 15; Mogens Trolle Larsen data o aparecimento da cidade-estado de Kaneš c. 2250 (Larsen 2015, xi); de acordo com Gojko Barjamovic, «when and how Assyrian trade in Anatolia began is lost in time. Direct textual evidence goes back to the early years of the reign of king Ikunum (1934-1921 BC), but a network of Assyrian trading colonies in Anatolia may have been established generations earlier» (Barjamovic 2011, 1).

${ }^{10}$ Bryce 2005, 18. 
de elementos populacionais hurritas do sudoeste ${ }^{11}$, cedo se estabelecendo a tensão hurro-hitita em território anatólico ${ }^{12}$. Hattušili I, cuja orientação política levaria a expansão hitita para o norte da Síria ${ }^{13}$, estaria também condenado ao confronto com os Hurritas do Mitanni, designadamente em torno de Uršu. Enquanto os esforços militares hititas estavam concentrados na zona de Arzawa, os Hurritas atacaram a Anatólia deixando incólume apenas a cidade de Huattuša ${ }^{14}$. Em resposta, Hattušili I avançou militarmente para leste e chegou mesmo a atravessar o Eufrates, seguindo-se o saque de despojos de guerra para Hुattuša, sem ser conseguido um domínio permanente sobre essas regiões. A guerra surge também neste caso como elemento propiciador do contacto étnico entre Hurritas e anatólicos ${ }^{15}$.

Nesta primeira fase da história hitita, antes de Tudhaliya I, o convívio com culturas não anatólicas não se limitaria ao Mitanni e ao norte da Síria, dado que Muršili I, legítimo sucessor de Hुattušili I, poria fim à dinastia de Hammurabi, com a breve conquista de Babilónia em $1531^{16}$. Este avanço militar pode bem ter tido a ajuda dos futuros governantes babilónicos, no âmbito de uma estratégia de aliança «internacional» de Muršili I com os Cassitas, motivada pela ameaça hurrita ${ }^{17}$. Durante a governação de Telipinu (c. 1510-1490), recomeçam as expedições contra as proximidades do recém-criado reino do Kizzuwatna, em Hुaššuwa, Zizzilipa e Lawazantiya ${ }^{18}$. Esta incursão militar não daria lugar à invasão do Kizzuwatna, pretendendo-se evitar novas hostilidades do Mitanni. Em todo o caso, as movimentações populacionais de semi-nómadas entre o Kizzuwatna e o Hatti continuaram após a morte de Telipinu, o que pode deduzir-se a partir do tratado estabelecido entre um dos monarcas hititas posteriores a Telipinu (talvez Huantili II) e Paddatiššu, rei do Kizzuwatna ${ }^{19}$. A integração de elementos étnicos hurritas na Anatólia pode assim ter ocorrido também na ausência de guerra.

${ }^{11}$ Bryce 2005, 61.

${ }^{12}$ Cf. Beckman 2007, 109-10: «The origins of the Old Kingdom and the process of its consolidation remain obscure to us, but it may now be recognized that Luwian and Hurrian influence was already present to a significant degree in the early Hittite state. We must therefore abandon any remnants of the view that a pristine Indo-European culture was gradually "Orientalized" in early Anatolia. At least during the period covered by the available texts, Hatti was always a multicultural civilization».

${ }^{13}$ Klengel 1998, 44.

${ }^{14}$ CTH 4, Anais de Ḩattušili I, obv. i, 24-26 (Carreira 1999, 48). CTH refere-se à numeração dos textos anatólicos seguida em Laroche 1971.

${ }^{15}$ Carreira 2009, 14.

${ }^{16}$ Eder-Renger 2007, 67.

${ }^{17}$ CTH 19, Edicto Constitucional de Telipinu, i 28 e ss. (Carreira 1999, 55), Bryce 2005, 99; cf. Klengel 1998, 64 e ss.

${ }^{18}$ Klengel 1998 79, Bryce 2005, 104.

${ }^{19}$ CTH 26 (KUB 34.1 17-20), trad. em Liverani 2001, 66-67; também em Beckman-Hoffner 1999,11 e ss. 
A conquista hitita de Alepo, iniciada por Hattušili I e concluída por Muršili I, provocou a desagregação das estruturas de poder no norte da Síria, facto que terá potenciado a infiltração de Hurritas nesse espaço territorial, travada apenas com o avanço de Tutmés I até ao Eufrates. A interrupção desta política de expansão egípcia durante o reinado de Hatchepsut permitiria uma grande expansão mitanniana para oeste, permitindo que Alepo se tornasse um reino vassalo do Mitanni de Parrattarna ${ }^{20}$. Os avanços militares egípcios na área do Mitanni criaram condições para que Zidanta II (ou Huzziya II) estabelecessem um pacto hitito-egípcio, dado que aqueles avanços militares se mostravam úteis para conter a ameaça hurrita no norte da Síria e apenas vagamente perigosos para pôr em crise o território anatólio.

Com Tudhaliya I inicia-se um novo período na história política do Hatti, essencialmente marcado pelo conflito aberto com os reinos vizinhos da Anatólia do Bronze Recente, assim se preparando o período imperial hitita de Šuppiluliuma I, meio século mais tarde. Nesta fase, observa-se já uma grande presença hurrita nos assuntos políticos hititas, nomeadamente aquando da querela sucessória e da rebelião de Muwa, bastante apoiada militarmente pelos Hurritas do Mitanni ${ }^{21}$. A hurritização da Anatólia tinha já atingido um tal estado de maturidade que tornava os grupos dominantes da sociedade hitita permeáveis à influência hurrita. No reinado de Tudhaliya I, o esforço de guerra a oeste, contra a Confederação de Aššuwa, enfraqueceu as fronteiras hititas a norte e a leste, potenciando a inimizade do reino de Išuwa, um território «tampão» entre o Hुatti e o Mitanni. As campanhas militares de Tudhaliya I naquele reino, bem como no norte da Síria, facilmente terão permitido a integração de novos sujeitos hurritas na Anatólia. Aliás, a hurritização da Anatólia ocorrida após Tudhaliya I ocorre também no espaço linguístico e religioso ${ }^{22}$.

Já com Arnuwanda I no trono hitita, o novo rei do Mitanni tentou dominar novamente o norte da Síria. Porém, a situação geopolítica incluía agora o interesse egípcio de Tutmés IV nessa região. Estabelecer-se-ia então um acordo mitano-egípcio, resultando na divisão da Síria em duas zonas de influência: a norte de Qadeš, do Amurru e de Ugarit, a intervenção seria hurrita, ficando os territórios a sul sob alçada egípcia. Tal acabaria por reforçar a presença política, e consequentemente étnica, hurrita no norte da Síria. A habilidade política e

${ }^{20}$ Bryce 2005, 116-17.

${ }^{21}$ Bryce 2005, 121.

${ }^{22}$ Watkins 2001, 51: «Hittite religion and the pantheon underwent a profound Hurritization from the Middle Hittite period onwards, and the language played a major role in ritual and cult, with numerous loanwords of varying degrees of assimilation». Klengel 1998, 113: «Durch die enge Verbindung mit Kizzuwatna wurde zweifellos auch der Einfluß hurritischer Kultur auf Hatti verstärkt, der sich vielleicht auch im hurritischen Namen der Gemahlin des Tuthalija, Nikkalmati [...], in den Namen späterer Königinnen sowie auch Zweitnamen der Großkönige zeigt». 
diplomática de Šuppiluliuma I (c. 1355/50-1320) daria expressão concreta ao imperialismo hitita, cuja maior expansão passaria pela inclusão de territórios mitannianos no Hुatti. Aliás, Šuppiluliuma I alimentou dissensões internas no Mitanni e aliou-se à Babilónia cassita, por meio do seu casamento com uma filha de Burnaburiaš II, com o objetivo último de derrotar aquele reino. As conquistas de Šuppiluliuma I na primeira campanha síria incliuriam Alepo, Mukiš, Niya, Arahtu, Qatna e Nuhašše (a norte de Aba apenas ficaria por conquistar Karkemiš $)^{23}$. Seguindo a política de Tudhaliya I, Šuppiluliuma I deportou as famílias reais dos conquistados para Hुattuša, inscrevendo a cultura dos vencidos no centro político do Hatti, vencidos esses que vinham de áreas fortemente hurritizadas, inclusive do próprio Mitanni.

Só na segunda campanha síria, também conhecida como Segunda Guerra Síria ou Guerra Hurrita, Šuppiluliuma I conseguiria submeter de vez o Mitanni e conquistar definitivamente Karkemiš. A profundidade da hurritização neste momento histórico do Hatti pode ser exemplarmente observada no facto de Piyaššili, filho de Šuppiluliuma I, indicado como vice-rei em Karkemišs, ter adotado o nome hurrita Šarri-Kušuh, ou ainda no facto de Šuppiluliuma I ter deixado os templos de Kubaba e da divindade LAMMA intactos após a conquista de Karkemiš: se a primeira deusa, originária da Alta Mesopotâmia, era cultuada na Anatólia desde o Reino Antigo, a segunda era uma divindade tipicamente hurrita ${ }^{24}$, com ocorrência na mitologia do Ciclo de Kumarbi, ambas convivendo agora tanto em Karkemiš como em Hुattuša. A fusão étnica hurro-hitita estava já convertida em cultura siro-anatólica de variada composição.

As vice-realezas criadas por Šuppiluliuma I, em Alepo e Karkemiš, ambas governadas por filhos de Šuppiluliuma I, Telipinu na primeira e Šarri-Kušuh na segunda, incluíam também a direção religiosa, tarefa igualmente desempenhada por Telipinu nos mais importantes centros religiosos da Síria ${ }^{25}$. A instituição da vice-realeza surge assim como instrumento de permanência da cultura hitita fora da Anatólia e como porta de entrada da cultura hurrita no poder hitita. Ou seja, a própria vice-realeza hitita terá hurritizado a Anatólia.

O reinado de Muršili II (c. 1318-1290), para além dos esforços militares a oeste, associados à continuidade da política deportacional seguida desde Tudhaliya $\mathrm{I}^{26}$, ficou marcado pelo caso de Tawannanna, a última esposa de Šuppiluliuma I, que permanecia como tawannanna em exercício ainda no reinado daquele soberano,

${ }^{23}$ Bryce 2005, 161.

${ }^{24}$ Hoffner 1998, 111. Note-se porém que a divindade ${ }^{\text {d} L A M M A ~ e r a ~ h u r r i t a ~ m a s ~ d e ~ o r i g e m ~}$ mesopotâmica.

${ }^{25}$ Bryce 2005, 188.

${ }^{26}$ Cf. por exemplo relativamente à população de Kathaituwa, CTH 61, Anais Completos de Mursili II, Ano 2 (Carreira 1999, 75). 
sendo simultaneamente sacerdotisa-šiwanzanni ${ }^{27}$. A acusação de Tawannanna de introduzir divindades simultaneamente babilónicas e hurritas em Hुattuša, no caso a divindade LAMMA, cujo templo de Karkemiš fora poupado por Šuppiluliuma I, aquando da Guerra Hurrita, mostra bem como a hurritização do espaço hitita chegara já ao âmago do poder político ${ }^{28}$. Aliás, a confirmação da elevada hurritização do Ḩatti no tempo de Muršili II vem logo a seguir, com o seu casamento com Tanu-ḩepa, uma princesa de provável origem hurrita cujo nome se relaciona com a paredra do deus hurrita Tešub: Hebat.

Também o futuro Hattušili III, ainda enquanto dirigente militar na Síria, se uniria à hurrita Puduhepa na cidade kizzuwatniana de Lawazantiya, sob a égide da deusa mesopotâmica Ištar ${ }^{29}$, um verdadeiro símbolo do conúbio étnico e cultural do Huatti imperial ${ }^{30}$. Puduhepa, cujo nome também parece remeter para a deusa hurrita Hebat, ordenou a recoleção e organização de textos religiosos do império, tendo propiciado uma profunda revisão dos rituais e das cerimónias hititas, ou agora melhor designadas hurro-hititas. O programa religioso de Puduhepa terá mesmo incluído a recitação do Ciclo de Kumarbi perante funcionários do palácio e dos templos de Hुattuša ${ }^{31}$. A assimilação de divindades hurritas no panteão hitita dava lugar a diversos processos de sincretismo, sendo exemplo a identificação da hurrita Hुebat com a hatiana Deusa Sol de Arinna ${ }^{32}$.

O império hitita teria o seu último momento de glória com Tudhaliya IV, nomeado rei pelo seu pai ainda em vida. A predominância hurro-hitita na

${ }^{27}$ Friedrich 1991, 195 s.v., indica a tradução «Gottesmuter», assim como Bryce 2005, 447 n. 71 propõe a tradução «mother of the god»; Tawannanna seria assim sacerdotisa da deusa mãe hitita.

${ }^{28}$ Cf. CTH 70 (KUB 14.4 ii 3-12), Muršili II Sobre o Caso Tawannanna: «Ó deuses não vedes como ela [Tawannanna] transformou a casa do meu pai na 'casa de pedra' [i.e. num mausoléu] do Deus Tutelar [LAMMA] e a 'casa de pedra' do deus? Algumas coisas ela trouxe da Terra de Šanḩara [i.e. de Babilónia]. Outras no Ḩatti [...] trouxe para a populaça. Ela não deixou nada... A casa do meu pai ela destruiu.» (apud Bryce 2005, 208). É notável que Muršili II se refira à divindade LAMMA como uma divindade da «Terra de Šanḩara» (Babilónia): a repulsa de Muršili II dirige-se à divindade por ser babilónica e não hurrita. Tal opção revela o quão a cultura hurrita estava já arraigada na Anatólia, a ponto de a natureza também hurrita de LAMMA ter de ser ignorada por Muršili para que o efeito político desejado fosse obtido: o afastamento de Tawannana.

${ }^{29}$ Cf. CTH 81, Apologia de Hattušili, $\$ 9$ (Carreira 1999, 138-39).

${ }^{30}$ Hattušili III e Puduhepa surgem representados no monumento de Fraktin, sendo Puduhepa aí designada por «filha do país de Kizzuwatna, amada pelos deuses» (cf. Yigit 2016, 61-62); «The Fraktin monument [...] which has figures and hieroglyph inscriptions on the rock wall is $1 \mathrm{~km}$ from the Zamantı River southeast of the Develi dates back to the period where the Hittite Kingdom was at its strongest period and was under the greatest Hurrian influence. The monument describes king Hattusili III who lived in the 13th century B.C. and his wife Puduhepe was the most important factor in the spread of Hurrian culture over the Hittite lands» (Yigit 2016, 61-62).

${ }^{31}$ Bryce 2002, 228.

${ }^{32}$ Cf. CTH 384, Oração de Puduhepa à Deusa Sol de Arinna (Pritchard 1969, 393). 
cultura anatólica, com integração de alguns elementos mesopotâmicos, se pode ser exemplificada pelo facto de o antepenúltimo rei hitita ser simultaneamente sacerdote de Ištar e do Deus Tempestade de Nerik, tem o seu máximo expoente em Yazılıkaya, o santuário ao ar livre que, existindo desde o início do Reino Antigo, atinge o seu maior desenvolvimento neste período. O panteão hurrita surge aí como o panteão hitita por excelência, com a tripla representação de Tudhaliya IV junto ao seu deus patrono Šarruma, o «deus da montanha» filho de Tešub e Hुebat, as duas divindades hurritas supremas. O cortejo de divindades hurritas representado em Yazilikaya concretiza plenamente o programa religioso iniciado por Puduhepa e Hattušili III.

Após o colapso do império hitita e do abandono progressivo de Hुattuša, no final do séc. XIII ${ }^{33}$, para além das persistências político-hititas em meio cultural hurrita, como se verificou por exemplo em Karkemiš, a herança cultural a que, à falta de melhor termo, se pode chamar hurro-hitita persistiu nalguns reinos neo-hititas. Em Tabal, zona de forte influência étnica luvita, também foi cultuada a deusa Kubaba, cujo principal centro de culto se localizou em Karkemiš, não obstante a sua origem alti-mesopotâmica e o seu culto anatólico no período inicial do reino hitita.

\section{DA DESORDEM À CONCÓRDIA}

Boa parte da mitologia hitita mais antiga está embutida em rituais destinados a superar momentos de crise, através da repetição ritual de um acontecimento primordial então invocado, um mugawar, ou então enquadra-se em festivais religiosos do Estado hitita, de que é exemplo o Mito de Illuyanka. O mito do Desaparecimento de Telipinu ${ }^{34}$ pode ser considerado paradigma dos mitos de divindades ausentes. Iniciando-se com o desaparecimento da divindade por razões indeterminadas, segue-se com a descrição da interrupção do curso normal da natureza, provocada pela ausência do deus. A repetição ritualizada associada ao mugawar traz de novo o deus e com ele o restabelecimento da ordem natural das coisas. A ausência de Telipinu provoca sofrimento não apenas no plano humano, mas também na esfera divina ${ }^{35}$. O sofrimento, metaforicamente

${ }^{33}$ "Archaeological evidence indicates widespread devastation by fire in the capital - on the royal acropolis, in the temples of both Upper and Lower Cities, and along stretches of the fortifications. This has conjured up the scenario of a royal capital succumbing all at one time to violent destruction in an all-consuming conflagration. / However Dr Seeher, the current director of excavations at Hattusa, has come to a rather less dramatic conclusion. His scenario is one of gradual abandonment of the capital, firstly by its royal family and leading members of the palace bureaucracy who took with them all their valuable and portable possessions, including the kingdom's most important official records. They must have done so once it became clear that the capital was doomed», Bryce 2005, 345.

${ }^{34} \mathrm{CTH} 324$, Desaparecimento de Telipinu.

${ }^{35}$ CTH 324, Desaparecimento de Telipinu, A obv. i 5-9 (García Trabazo 2002, 111): «A 
provocado pelo fumo, atinge igualmente homens e deuses, que ficam tão sufocados nos seus altares como homens e animais o ficam nos seus habitates ${ }^{36}$.

Há assim uma interdependência no plano divino expressa no mito do Desaparecimento de Telipinu, ainda que Telipinu não seja colocado em nível hierarquicamente superior aos outros deuses. A ausência da divindade revela a sua importância para a manutenção do equilíbrio cósmico, sobressaindo assim uma ideia de harmonia perdida quando uma das divindades se ausenta. Essa mesma correlação ocorre no mito do Desaparecimento do Deus Tempestade ${ }^{37}$, quando sucede um desaparecimento similar, ou até nos mitos do Deus Tempestade de Kuliwišna ${ }^{38}$, do Deus do Escriba Pirwa ${ }^{39}$ e do Deus Tempestade da Rainha Harapšiliti ${ }^{40}$ A conceção de concórdia entre deuses nos mitos de divindades ausentes, que se expande para o plano humano, tende assim a caracterizar o poder, do ponto de vista mitológico, como uma harmonia quase não hierárquica, assente na necessidade que os deuses têm uns dos outros: todos são imprescindíveis para que haja equilíbrio e abundância no plano divino. O próprio facto de todos os deuses participarem no banquete organizado pelo Deus $\mathrm{Sol}^{41}$ denota a ausência de rivalidade divina. Tal situação pode estar relacionada com a pouca especulação teológica, ou mesmo com a ausência de uma teologia em sentido estrito, nos períodos anteriores a Hुattušili III e a Puduhepa ${ }^{42}$.

A tendência não hierárquica dos mitos de divindades ausentes assume por vezes registos de complementaridade funcional, reconhecendo-se uma dependência da conjunção das divindades para obter benefícios. Tal sucede no passo do mito As Fiandeiras Infernais, associado ao Ritual Para a Construção de um Novo Palácio ${ }^{43}$, onde se relaciona o par divino formado pela Deusa Sol e pelo Deus Tempestade, ambos fenómenos celestes divinizados:

neblina tomou as janelas, o fumo [tomou] a casa; / os lenhos consumiram-se na lareira, os deuses sufocaram-se / [nos altares], também as ovelhas no curral, [e] as vacas / sufocaram-se no estábulo; a ovelha abandonou o seu cordeiro / e a vaca abandonou o seu vitelo».

${ }^{36}$ Situação semelhante ocorre, por exemplo, no mito do Deus do Escriba Pirwa (CTH 328) (Pecchioli Daddi-Polvani 1990, 106).

${ }^{37}$ CTH 325, Desaparecimento do deus Tempestade, \$5, A i 16-21 (Hoffner 1998, 21).

${ }^{38}$ CTH 329, O Deus Tempestade de Kuliwišna, ii 5 ss. (Pecchioli Daddi-Polvani 1990, 108).

${ }^{39}$ CTH 328, O Deus do Escriba Pirwa, KUB 33.32 ii 5' e ss. (Pecchioli Daddi-Polvani 1990, 107). Situação semelhante se observa no mito Anzili e Zukki (CTH 333), com a diferença que a desordem cósmica não é provocada pelo desaparecimento de um deus, mas causada pela irritação de Anzili e de Zukki; cf. Bernabé 1987, 72 ss.

${ }^{40}$ CTH 327, O Desaparecimento do Deus Tempestade da Rainha Harapšili, $₫ 3$, A iii 1-4 (Hoffner 1998, 25): «[O Deus Tempestade da Rainha Harapšili(?)] sentou-se numa cadeirašarpas de madeira. [...]. A neblina libertou [a janela]. [O fumo] libertou [a casa]. O altar estava de novo em harmonia. [Acima dele] os deuses estavam em harmonia.»; cf. \$8, D 10-17.

${ }^{41}$ Cf. CTH 329, O Deus Tempestade de Kuliwišna, ii 5 ss. (Pecchioli Daddi-Polvani 1990, 108) e CTH 328, O Deus do Escriba Pirwa, obv. i 15' e ss. (Pecchioli Daddi-Polvani 1990, 106).

${ }^{42}$ Bryce 2002145.

${ }^{43}$ CTH 414, Ritual para a Construção de um Novo Palácio. 
«[...] e invoquei a (deusa) Trono, minha amiga: 'Não (eras) tu minha amiga, do rei? Proporciona-me essas árvores, e (eu) as cortarei” E a Deusa Trono responde / ao rei: "Corta-os, corta(-os)! A Deusa Sol / e o Deus Tempestade proporcionaram-tos." ${ }^{44}$

Por vezes, aquela conceção não hierárquica do poder divino dá lugar a uma certa pusilanimidade divina, como se pode observar no passo do mito A Lua Caída do Céu em que o Deus Tempestade sente medo e angústia pelo desaparecimento do Deus Lua ${ }^{45}$. Observa-se aqui a ausência de uma conceção de poder competitivo e belicoso, antes se promovendo uma certa humanização das divindades, pois o Deus Tempestade surge aqui afastado de um ideal de coragem e valentia bélica, desembocando mesmo na pusilanimidade do medo.

Nas relações de poder dos mitos de divindades ausentes também há lugar para a superioridade de algumas entidades, sempre sem recurso à categoria de realeza para estratificar o divino. Pode ter-se Hannahanna como exemplo dessa discriminação, dado ser esta deusa que, no mito do desaparecimento de Telipinu, ordena ao Deus Tempestade que procure o deus ausente ${ }^{46}$. Concebe-se assim uma certa diferenciação política na «sociedade» divina, porventura decalcando a importância política da tawananna hitita. Porém, a discriminação positiva desta deusa parece assentar na sua natureza de sage conselheira ${ }^{47}$. A discriminação de Ḩannahanna no meio divino evidencia também a projeção das relações familiares de autoridade dos antepassados no campo do mito.

${ }^{44}$ CTH 414, Ritual para a Construção de um Novo Palácio, A obv. i 34-38 (García Trabazo 2002, 489). Nova referência ao par divino formado pela Deusa Sol e pelo Deus Tempestade ocorre no mesmo mito em A obv. ii 47-49 (García Trabazo 2002, 499); também noutros mitos de divindades que desaparecem surgem referências a outros pares divinos, como por exemplo o par Deus Tempestade - Deusa Sol de Arinna nos fragmentos CTH 335.

${ }^{45}$ CTH 727, A Lua Caída do Céu, C obv. ii 10-14 (García Trabazo 2002, 261). A mesma ideia em A obv. ii 16-21. Nova referência ao medo e à angústia do Deus Tempestade surge na parte ritual do mito A Lua Caída do Céu (CTH 727, C rev. iii 10'-11'), ainda que aqui com a possibilidade destas emoções se referirem ao efeito das ações do Deus Tempestade no plano humano, num comum momento de projeção das preocupações humanas no divino. Cf. García Trabazo 2002, 265.

${ }^{46}$ CTH 324, Desaparecimento de Telipinu, A obv. i 29-32 (García Trabazo 2002, 115); cf. ainda CTH 324, Desaparecimento de Telipinu, E obv. ii 15'-16' (García Trabazo 2002, 117) e CTH 336, Mitos da Deusa Inara, $\$ 3$ B ii 4-9 (Hoffner 1998, 30).

${ }^{47}$ E.g. CTH 336, Mitos da deusa Inara, $\$ \$ 1-2$, ii 1-10 (Hoffner 1998, 31). A diferenciação positiva de Hannahanna, enquanto conselheira sábia, também pode ser observada na parte final de CTH 336 (Mitos da Deusa Inara, \$\$4-6, A rev. 2-13; Hoffner 1998, 32): «Quando estiveres perante o Deus Sol, não faças de novo [...] tudo. Tu irás e encontrarás [...]. Tu dirás [...]. Quando o Deus Sol disser: 'Tu, faz alguma coisa., ele diz: 'Tu, [...]'. Mas se ele nada disser, deixa-o estar em silêncio(?)." O Deus Guerra respondeu: "Mas se eu não for a lado nenhum, que devo levar?" Hannahanna respondeu-lhe: "Ano a ano, continua a ir para campanhas militares." As três crianças da Serva Feminina [perguntaram] a Hannahanna: "Espera, que devo levar?" [Hannahanna respondeu]: "Ide [...]! Não vás [...]!"». 
Aliás, o seu nome significa literalmente «mãe da mãe», ou seja «avó ${ }^{48}$, tendo a sua autoridade paralelo na figura do avô do Deus Tempestade referido no mito do Desaparecimento do Deus Tempestade ${ }^{49}$. Contudo, a tónica dos mitos de divindades ausentes está na relativa igualdade e capacidade de convivência entre deuses.

O carácter não hierárquico e coletivo do poder, nos mitos de divindades ausentes, parece divergir da conceção de superioridade do Deus Tempestade no interior do panteão anatólico, pois cedo foi considerado garante da ordem cósmica e supremo protetor da "Terra do Huatti», com o rei a desempenhar a função de seu deputado na terra ${ }^{50}$. Porém, tal posição, manifestada cultualmente, não teve correspondência mitológica, com a possível exceção do mito do Desaparecimento do Deus Sol, como mais à frente se discutirá. Releva ainda que as relações entre deuses, de acordo com os mitos de divindades ausentes, excluam de todo a categoria de rei divino. Mesmo em situação de policefalia divina, na sua essência, as conceções de poder dos mitos de divindades ausentes não incluem o exclusivismo do mando.

\section{O DEUS E A SERPENTE}

A harmonia essencial dos mitos de divindades ausentes, excluindo o mito do Desaparecimento do Deus Sol ${ }^{51}$, não tem paralelo noutros mitos anatólicos antigos. No Mito de Illuyanka $a^{52}$, a harmonia divina dá lugar à modalidade de luta entre um deus e uma força má. Em ambas as versões do Mito de Illuyanka, o Deus Tempestade, derrotado pela serpente num primeiro combate, procura uma segunda oportunidade para reaver a sua superioridade bélica perante o terrível ofídio. Na primeira versão, Inara procura a ajuda do humano Hupašiya e, na segunda versão, o Deus Tempestade recorre a uma humana, à «filha de um pobre», para engendrar um filho que o ajudará a reaver os olhos e o coração que perdeu no primeiro combate. Em ambas as versões se pode presenciar uma modalidade de luta de recuperação do poder, em ambas se instrumentalizando um humano como estratégia de recuperação do poder. No entanto, esta instrumentalização varia da primeira para a segunda versão do mito: na primeira, é uma deusa que usa um humano, Hupašiya; na segunda, um deus socorre-se de uma mulher, a «filha de um pobre». No primeiro caso, o divino feminino instrumentaliza o humano masculino, no segundo caso o divino masculino instrumentaliza o feminino humano.

\footnotetext{
${ }^{48}$ Cf. Friedrich 1991, 50 s.v. hanna-.

${ }^{49}$ Cf. CTH 325, Desaparecimento do Deus Tempestade, $\$ 9$, A i 34-36 (Hoffner 1998, 21).

${ }^{50}$ Bryce 2002, 143; cf. Gurney 1954, 140.

${ }^{51}$ CTH 323.

${ }^{52}$ CTH 321.
} 
A ausência de tensão no exercício do poder revelada nos mitos de divindades ausentes transforma-se assim numa conceção de poder repetidamente ameaçado e recuperado, conceção que decorrerá da ligação deste mito ao Purulli, um dos mais importantes festivais anuais do calendário hitita. Tão importante que Muršili abandonou uma campanha militar para o celebrar, tendo como propósito revigorar as terras depois do duro inverno e assim assegurar a persistência da chuva necessária às culturas. Desta forma, o combate ritual entre o Deus Tempestade e Illuyanka, cujo nome parece significar «serpente» ${ }^{53}$, simboliza o triunfo da vida sobre a morte, da fertilidade sobre a seca, i.e., a vitória do bem sobre o mal.

Da perspetiva de conceção de poder, a derrota inicial do Deus Tempestade não implica ainda um problema de obtenção de realeza divina, dada a diferente categoria dos opositores: por um lado um deus, por outro uma força hostil. O motivo inicial da luta poderá antes ser interpretado como uma luta pelo controlo das águas necessárias à agricultura, em que o Deus Tempestade domina as águas pluviais e a serpente as águas subterrâneas, até porque o ritual associado ao mito se desenvolveria junto a uma fonte, sendo assim uma projeção, na conceção do divino, da luta humana pela água, a fundamental preocupação do festival $P \mathcal{H}$ rulli ${ }^{54}$. Em essência, o Mito de Illuyanka constitui uma estória de recuperação do poder, com preponderância da divindade em detrimento da força má. Não deixa de ser significativo que o nome do opositor do deus, Illuyanka, seja um lexema de significação geral, indicando apenas o seu ofidiomorfismo, ao passo que o nome hitito-luvita do Deus Tempestade, Tarhunza, signifique «o poderoso»" Contudo, a posição do Deus Tempestade perante os seus pares varia de acordo com o seu sucesso perante Illuyanka. Após a derrota inicial, na primeira versão do mito, o Deus Tempestade parece ser abandonado pelos restantes deuses e assim conta apenas com a fidelidade de sua filha Inara ${ }^{56}$. Porém, após vencer a serpente, restabelece-se a sua autoridade e a sua reputação de deus capaz e poderoso ${ }^{57}$, numa situação semelhante ao reconhecimento do poder de David pelo Deus dos Hebreus, após haver consolidado a sua soberania política ${ }^{58}$.

$\mathrm{O}$ opositor do Deus Tempestade também não aparece caracterizado como especialmente dotado de poder. Na primeira versão do mito, Illuyanka

${ }^{53}$ García Trabazo 2002, 85 n. 27.

${ }^{54}$ Pecchioli Daddi-Polvani 1990, 40-41; Macqueen 1959, 175.

${ }^{55}$ O nome Tarhunt- ou Tarhu(na) deriva da raíz tarh-, que significa "poder»; García Trabazo 2002, 37. No Mito de Illuyanka ocorrem os sumerogramas d ${ }^{\mathrm{U}}$ e ${ }^{\mathrm{d}} \mathrm{IM}(-)$.

${ }^{56}$ Pecchioli Daddi-Polvani 1990, 41. Cf. CTH 321, Mito de Illuyanka, A obv. i 11-14 (García Trabazo 2002, 86-87).

${ }^{57}$ CTH 321, Mito de Illuyanka, B obv. i 17'-18' (García Trabazo 2002, 89): «Chegou o Deus Tempestade e matou a serpente. / E os deuses estavam com ele».

${ }^{58}$ 2Cr 1:1: «Salomão, filho de David, consolidou-se no seu reino. O Senhor, seu Deus, estava com ele e engrandeceu-o no poder». 
é imobilizada pela ação do humano Hुupašiya, não por alguém especialmente poderoso, e em consequência da sua gulodice. Tal como noutras áreas mitológicas, a serpente é vista como um glutão desfavorecido pela estupidez, à semelhança do que conta Opiano na Halieutica ${ }^{59}$, acerca de como Pã de Córico enganou Tífon oferecendo-lhe um banquete de peixe, assim conseguindo que o monstro saísse do seu covil para depois ser atacado por Zeus ${ }^{60}$. A estupidez dos opositores ao poder, contudo, tem registo também nas narrativas mitológicas hurritas, designadamente no que diz respeito a Ullikummi e a Hedammu, como teremos oportunidade de verificar.

Não deixa de ser notável que a luta entre o Deus Tempestade e Illuyanka esteja estruturada em torno de dois princípios: um celeste, representado pelo Deus Tempestade, e um ctónico, representado pela serpente, oposição esta que aparecerá também nas narrativas mitológicas hurritas, ainda que travestida de dinastias reinantes em competição. Ainda que o Mito de Illuyanka centre a sua atenção sobre o Deus Tempestade, não pode negligenciar-se o papel de Inara que, segundo pesquisas recentes, não teria um papel subordinado na mitologia associada ao Purulli ${ }^{61}$. Esta posição reforça a ideia de que o poder, nos mitos anatólicos antigos é tendencialmente horizontalizado, ainda que perturbado por forças más. Ainda assim não possui aquela estrutura verticalizada das narrativas hurritas importadas para o Hatti.

\section{Realeza, VerTiCAlizaÇÃo E CiClo COMPleXo}

Diversos textos em língua hurrita foram incorporados na cultura hitita, designadamente fragmentos de presságios, textos históricos e histórico-mitológicos, diversos rituais, listas de divindades e outros textos ${ }^{62}$. Concomitantemente, com a hurritização étnica e política da Anatólia, diversas narrativas mitológicas hurritas foram integradas na matriz hitita, provocando fenómenos de adição, assimilação e sincretismo mítico e religioso. $\mathrm{O}$ mais importante aporte tem hoje o nome de Ciclo de Kumarbi. Composto por cinco «cantos» mais um - O Canto de Kumarbi ${ }^{63}$, O Canto do Deus LAMMA ${ }^{64}$, O

\footnotetext{
${ }^{59}$ Opp. H. 3.15-25.

${ }^{60}$ Bernabé 1987, 32. A. Bernabé aponta ainda a semelhança de Illuyanka com Tífon em Apolodoro (1.6.3), que prova os «frutos efémeros» e por isso fica debilitado.

${ }^{61}$ Hoffner 1998, 10.

${ }^{62}$ Dentre os textos hurritas mencionados, avultam os rituais, designadamente da série itkalzi e itkahhe, bem com o importante Ritual de Allaiturahi (CTH 780), este último existente também em versão hitita (cf. Wegner 200730 e ss.); cf. CTH 774-791.

${ }^{63} \mathrm{CTH} 344$.

${ }^{64}$ CTH 343.
} 
Canto de Prata ${ }^{65}$, O Canto de Hedammu ${ }^{66}$ e o Canto de Ullikummi ${ }^{67}$, a que se adicionou recentemente $O$ Canto da Libertação $0^{68}$-, tem por tema principal a ascensão de Tešub à realeza divina, seguida da sua resistência aos ataques que sofre por parte de vários opositores, uma boa parte conduzida por Kumarbi. O título dado a todo o ciclo reflete o facto de a maior parte das narrativas que o integram constituirem a estória do ressentimento de Kumarbi perante a perda da realeza, ganha por Tešub logo no Canto de Kumarbi. O ressentimento, cujo importantíssimo papel histórico foi já evidenciado por Marc Ferro ${ }^{69}$, assume o papel de motor em todo O Ciclo de Kumarbi.

A introdução do tema da competição pelo lugar de rei entre os deuses surge como um dos mais importantes contributos hurritas para a mitologia anatólica, o que pode bem ter sido mais-valia para os reis hititas, visto promover a própria instituição da realeza humana através da congénere divina ${ }^{70}$. No Canto de Kumarbi, estabelece-se uma sucessão real divina iniciada por Alalu, seguida por Anu e Kumarbi e finalizada com Tešub. Diferentemente de toda a mitologia hitita antiga, as narrativas mitológicas hurritas introduzem a ideia de gerações de deuses que governam uns após os outros, com a particularidade das gerações mais novas de deuses lutarem com as mais velhas pela obtenção do assento real.

A sucessão real do Canto de Kumarbi narra como o poder andou de mão em mão até ser finalmente estabelecido por Tešub, dando início a uma nova era divina, com a particularidade de a instabilidade do poder, antes de Tešub o conseguir, derivar da tensão entre duas linhagens de soberanos, com Alalu e Kumarbi a representar uma família e Anu e Tešub a representar outra. Assim, a hurritização dos conteúdos mitológicos hititas passou também pela importação do tema da rivalidade familiar entre divindades, diferentemente do que se passa, por exemplo, no Mito de Illuyanka, em que a oposição não é entre famílias divinas mas sim entre um princípio de bem, o Deus Tempestade, e outro de mal, Illuyanka.

As duas famílias divinas em competição representam as duas esferas básicas da mitologia hurrita: o mundo inferior e o domínio celeste. Se o próprio nome Anu significa «céu», quando Alalu é afastado do trono, foge para a «Terra Escura». E Anu, quando tenta escapar a Kumarbi, dirige-se para o céu ${ }^{71}$. Esta

${ }^{65}$ CTH 364.

${ }^{66} \mathrm{CTH} 348$.

${ }^{67}$ CTH 345.

${ }^{68}$ Recente número CTH 789. A edição standard do texto é de Neu 1996. Até 1971, apenas o Canto de Kumarbi, o Canto do Deus LAMMA e o Canto de Ullikummi eram considerados partes integrantes do Ciclo de Kumarbi (Hoffner 1998, 40).

${ }^{69}$ Ferro 2009.

${ }^{70}$ Bryce 2002, 228.

${ }^{71}$ CTH 344, Canto de Kumarbi, A obv. i 12-14, 18-22 (García Trabazo 2002, 163-65): 
rivalidade entre aquelas duas esferas, o céu e o mundo inferior, ganha relevância na sua continuidade no conjunto de figuras míticas que alinham por um lado ou por outro ao longo de todo o Ciclo de Kumarbi: Alalu, Mukišanu (vizir de Kumarbi), o Grande Deus Mar, Impaluri (vizir do Deus Mar), Šertapšuruhi (filha do Deus Mar), Hedammu, Daganzipa (Terra), Prata, Ullikummi, as Divindades Irširra e provavelmente Upelluri alinham pelo lado de Kumarbi, ao passo que Anu, Tašmišu/Šuwaliyatta, Hebat, Takiti (serva de Hebat), Šawoška/ Ištar, os touros divinos Šerrišu e Huurri, o Deus Sol, o Deus Lua, o Deus Guerra Aštabi, o rio Aranzah (irmão de Tešub), o deus montanha Kanzura, KA.ZAL e NAM.HÉ estão do lado de Tešub ${ }^{72}$. Este conflito de base familiar ou dinástica pode evidenciar o sentido inicial de um anterior mito, antes de chegar à forma hurrita literariamente elaborada que chegou aos Hititas, dado que este pode bem ser vestígio de um anterior mito ritualizado, cuja estrutura central passaria pela oposição entre as forças do mundo inferior e as do mundo superior, com o triunfo destas últimas ${ }^{73}$.

A importância das ideias de linhagem e de família no Ciclo de Kumarbi pode ser observada, por exemplo, no Canto de Prata, quando Prata se sente envergonhado por ser reputado órfão ${ }^{74}$. Nesse episódio, sublinha-se a importância da paternidade e da linhagem familiar para a afirmação «social» do deus no mundo divino, refletindo essa mesma relevância no plano humano através do habitual fenómeno de projeção mitológica de inquietações terrenas. Aliás, neste passo, o poder paternal parece sobrepor-se ao poder real, pois a mãe de Prata sublinha o temor reverencial que o filho deve ter perante o seu pai, mas não perante Tešub, o rei em exercício. Concomitantemente, no Ciclo de Kumarbi, a preponderância das relações familiares, com especial ênfase no papel do pai, observa-se ainda

«Durante nove anos contados Alalu foi rei no céu; no nono ano / Anu batalhou contra Alalu, vencendo-o a ele, a Alalu. / E este fugiu diante dele e para baixo da Terra Escura; / [...] / Durante nove anos contados foi Anu rei no céu; no nono ano Anu / batalhou contra Kumarbi. Kumarbi semente de Alalu, / batalhou contra Anu. Anu já não resiste / aos olhos de Kumarbi, e, de Kumarbi, lhe escapou / das mãos; e ele, Anu, voou e foi para o céu».

${ }^{72}$ Hoffner 1998, 41.

${ }^{73}$ Bryce 2002, 225.

${ }^{74}$ CTH 364, Canto de Prata, $\$ \$ 3.2-3.3$ (Hoffner 1998, 49): «Prata [bateu] a um rapaz órfão [com] um pau. O rapaz órfão respondeu mal a Prata: "Ó Prata, porque [nos estás a bater]? Porque nos bates? Tu és um órfão como nós." [Agora, quando Prata ouviu estas palavras], ele começou a chorar. Chorando, Prata foi para sua casa. Prata começou por repetir as palavras a sua mãe: "Os rapazes a quem eu bati em frente do portão desafiaram-me. Eu bati a um rapaz com um pau e ele respondeu-me mal. Ouve, ó minha mãe, as palavras que o rapaz órfão me disse: 'Porque [nos] estás a bater? [Porque nos] bates? [Tu és um órfão como nós.] [...] [resposta da mãe de Prata:] "[O teu pai(?) é Kumarbi], o pai da cidade de Urkiš. [Ele...], e ele vive em Urkiš. [...] as causas legais de todas as terras ele [satisfatoriamente] resolve(?). O teu irmão é Tešub. Ele é rei no céu. E ele é rei na terra. A tua irmã é Šawoška, e ela é rainha em Nínive. Tu [não] deves recear nenhum [outro deus]; só um deus [deves recear. Ele (i.e. Kumarbi) agita] as terras inimigas e os animais selvagens». 
no facto de, no Canto de Prata, Tešub medir as suas próprias capacidades com as do pai de Prata, após este conseguir temporariamente a realeza ${ }^{75}$. Kumarbi, o pai de Prata, continua a ser a medida e o termo de comparação para a decisão de Tešub em combater ou não.

Também no Canto de Hedammu se pressente a importância do instituto da paternidade no estabelecimento das relações de poder entre as divindades, especialmente quando Kumarbi, o rei deposto, num período em que tudo indica que Tešub está no poder, pretende realizar uma aliança política com o Deus Mar, continuando a intitular-se "pai dos deuses», pretendendo manter o seu ascendente através desta titulatura ${ }^{76}$. Aliás, Kumarbi volta a recorrer a esta titulatura no Canto de Ullikummi ${ }^{77}$. A oposição de famílias divinas no Ciclo de Kumarbi, cada uma delas com uma alocação própria, pode também ser encarada como paralela ao ocorrido no Mito de Illuyanka, em que o Deus Tempestade representa a esfera celeste e Illuyanka o mundo inferior.

O facto de, no Canto de Kumarbi, o poder ser sempre transmitido pela via belicosa, até chegar a Tešub, pode também representar mitologicamente a belicosidade do poder político no domínio hurrita ou, por outro lado, fazer entender a narrativa mitológica como meio de representação do extraordinário em relação à ordem política humana, fazendo do mito transformado em narrativa uma representação do traumático, com a memória coletiva a guardar o mais doloroso ou perigoso para a comunidade, à semelhança do mais fundo registo dos insucessos na memória individual, um reflexo do instinto de preservação. Também neste aspeto as narrativas mitológicas hurro-hititas se distinguem dos mitos anatólicos antigos, dada a tónica na superação da desordem (nos mitos associados a rituais do tipo mugawar) ou na vitória do bem sobre o mal (no Mito de Illuyanka), centrando os mitos hititas antigos na solução para o distúrbio, mais do que no registo do traumático.

O Canto de Kumarbi assemelha-se ao Mito de Illuyanka no facto de ambos começarem por favorecer o princípio ctónico e acabarem por outorgar a vitória ao princípio celeste. A narrativa mitológica hurrita, dado que apresenta Anu como um cobarde que foge do combate por si iniciado, dirigindo-se para o céu, na sequência do que Kumarbi o traz de novo ao combate, parece favorecer inicialmente a linhagem de Kumarbi, mas posteriormente outorga o triunfo à

${ }^{75}$ CTH 364, Canto de Prata, $\$ \$$ 5.1-5.2 (Hoffner 1998, 50): «[Tašmišu começou] por dizer a Tešub: "Não [é possível(?)]que tu trovejes? Tu [não] sabes [como...]? $\mathrm{Na}($ ?)... [Prata(?)] tornou-se rei e [agora] ele [conduz(?)] todas as divindades com um aguilhão(?) de madeira de pistacho." Tešub [começou por] responder ao seu vizir: "Vá, vamos e comamos [...]. O nosso pai, [Kumarbi(?)], não derrotou [Prata(?). Será que nós] agora [vamos derrotar] Prata?"».

${ }^{76}$ CTH 348, Canto de Hedammu, $\$ 9.3$ (Hoffner 1998, 53).

${ }^{77}$ CTH 345, Canto de Ullikummi, $\$$ 6, A ii 1-8 (Hoffner 1998, 57). 
linhagem celeste, i.e., a Tešub ${ }^{78}$. De igual modo, no Mito de Illuyanka, a serpente vence o primeiro combate com o Deus Tempestade mas este acaba por obter a vitória final. $O$ poder obtido pelo deus celeste Tešub no final da sucessão real, no Canto de Kumarbi, surge sempre ameaçado por descendentes de Kumarbi: Ullikummi resulta da união sexual de Kumarbi com um rochedo, Hedammu muito possivelmente é filho de Kumarbi e Šertapšuruhi, Prata descende de Kumarbi e de uma humana mortal e mesmo LAMMA pode talvez ser filho de Kumarbi ${ }^{79}$. Assim, a complexidade das narrativas mitológicas hurritas não parece ter paralelo nos mitos anatólicos antigos, com a possível exceção do mito do Desaparecimento do Deus Sol.

Não obstante, a derrota inicial do deus celeste, colocando em risco a sua vitória final, pode constituir um paralelo entre o Mito de Illuyanka e parte do Ciclo de Kumarbi. Assim como o Deus Tempestade é derrotado inicialmente, também Tešub, no Canto de Ullikummi ${ }^{80}$, é derrotado por Ullikummi no primeiro combate entre eles.

A hurritização dos conteúdos mitológicos hititas concretizou-se também na adoção de mais complexas estruturas de poder, agora repartido por várias instâncias, não obstante a introdução também hurrita da categoria de realeza divina. No Canto do Deus LAMMA, o poder real surge vinculado a um poder moderador concretizado em Ea, o deus mesopotâmico da sabedoria adotado pelos Hurritas do Mitanni ${ }^{81}$. Perante a arrogância de LAMMA, durante o seu breve reinado no céu, Ea, que antes o havia designado rei, depõe-no do trono divino, num ato caracterizador de Ea como poder moderador da realeza, um tanto à semelhança do ugaritiano Ilu nos textos do Ciclo de $\mathrm{Ba}$ 'lu, mormente no mito da Luta Entre Ba'lu e Yammu ${ }^{82}$. Também no Canto de Hedammu Ea intervêm na refrega entre Kumarbi e Tešub, advertindo-os e fazendo questão de dizer que também a ele chamam «rei $»^{83}$. Porém, a moderação exercida por

${ }^{78}$ CTH 344, Canto de Kumarbi, A obv. i 18-26 (García Trabazo 2002, 165-67): «Durante nove anos contados foi Anu rei no céu; no nono ano Anu / batalhou contra Kumarbi. Kumarbi semente de Alalu, / batalhou contra Anu. Anu já não resiste / aos olhos de Kumarbi, e, de Kumarbi, lhe escapou / das mãos; e ele, Anu, voou e foi para o céu. / Por detrás, aproximou-se dele Kumarbi e agarrou Anu pelos pés / e puxou-o para baixo desde o céu. / Mordeu os seus músculos; a sua virilidade uniu-se, como o bronze, com as entranhas / de Kumarbi».

${ }^{79}$ Cf. Hoffner 1998, 41.

${ }^{80}$ CTH 345, Canto de Ullikummi, $\$ \$$ 40-42 e 49 (Hoffner 1998, 61-63). A tabuinha que conteria a derrota inicial de Tešub face a Ullikummi está bastante fragmentada e não permite uma completa leitura deste episódio, contudo, o facto de, no $\$ 49$, Tešub se preparar para novo combate com Ullikummi demonstra que o primeiro enfrentamento não foi favorável ao deus celeste.

${ }^{81}$ CTH 343, Canto do Deus LAMMA, $\$ \$$ 6-8, A iii 1-38 (Hoffner 1998, 47-48).

${ }^{82}$ KTU 1.1, 1.2. KTU refere-se à numeração dos textos ugaritianos seguida em Dietrich-Loretz-Sanmartín 1995. Trad. de KTU 1.1-1.2 em Olmo Lete 1981, 157-77.

${ }^{83}$ CTH 348, Canto de Hedammu, $\$ \$$ 6.1-6.2 (Hoffner 1998, 52). 
Ea não está livre de protesto, especialmente da parte de Kumarbi, que decide criar Hedammu com o propósito de derrubar o rei divino em exercício, julgando assim escapar à anterior reprimenda de Ea, dirigida a obter a conciliação entre Tešub e Kumarbi ${ }^{84}$.

O papel de moderador na luta pelo poder, no Canto de Hedammu, evoluirá para a tomada de partido por Tešub no Canto de Ullikummi. Tašmišu aconselha Tešub, derrotado no primeiro combate contra Ullikummi, a procurar a ajuda de $\mathrm{Ea}^{85}$, que então descobre o segredo do poder de Ullikummi, o apoio do seu pé no ombro direito de Upelluri. Ea e as Divindades Primevas usam então a faca de cobre primeva, antes usada na separação o céu da terra, para arrancar Ullikummi do seu apoio em Upelluri ${ }^{86}$, facilitando assim o "caminho para o poder» de Tešub. Porém, a ação de Ea em prol de Tešub não segue sem arrependimento, visto que, após o enfraquecimento de Ullikummi, Ea entristece-se ao ver as mortes provocadas pela luta entre Tešub e o monstruoso filho de Kumarbi ${ }^{87}$.

A estruturação do poder nos mitos hurritas incluiu não só a conceção de poderes moderadores, caso de Ea, mas também de instâncias de poderes conselheiros, como o de Šerrišu no Canto de Kumarbi, que aconselha Tešub a não amaldiçoar os deuses e especialmente $\mathrm{Ea}^{88}$. A mesma instância de poder conselheiro pode ser encontrada na figura do vizir, seja do rei em exercício, seja de Kumarbi. Quando Ullikummi se aproxima dos portões de Kummiya, a cidade de Tešub, Tašmišu, irmão e vizir do rei, aconselha-o a pedir ajuda a Ea ${ }^{89}$. De certo modo, esta ativa instância conselheira dos mitos hurritas é paralela à função de Hannahanna nalguns mitos de divindades ausentes ${ }^{90}$. O conselho que o poder em exercício obtém deriva também em poder sancionatório quando se trata de Kumarbi. Depois de este se unir a uma rocha, Ullikummi acaba por nascer com a ajuda das Deusas Destino e das Deusas Mãe ${ }^{91}$, estas que, para Kumarbi, lhe

${ }^{84}$ CTH 348, Canto de Hedammu, $\$ 7.1$ (Hoffner 1998. 52-53).

${ }^{85}$ CTH 345, Canto de Ullikummi, $\$ 49$, A ii 17-26 (Hoffner 1998, 56).

${ }^{86}$ CTH 345, Canto de Ullikummi, $\$ \$ 56-60$, A iii 1-39 (Hoffner 1998, 63-64).

${ }^{87}$ CTH 345, Canto de Ullikummi, $\$ 65$, A iv 9-12 (Hoffner 1998, 64).

${ }^{88}$ CTH 344, Canto de Kumarbi, $\$ 20$, A iii 30-39 (Hoffner 1998, 45): «O touro Šerrišu respondeu a Tešub: "Meu senhor, porque os estás a amaldiçoar, [... os...] deuses? Meu senhor, porque os [estás a amaldiçoar]? Porque estás a amaldiçoar também Ea? Ea ouvir-te-á [...] com... Não é assim? [...] é grande. O mal é grande como a terra. Poderoso(?) para ti [é...]. [...] virá. Tu não serás capaz de levantar [o teu(?)] pescoço(?).”».

${ }^{89} \mathrm{CTH} 345$, Canto de Ullikummi, $\$ \$ 48-49$, A ii 10-19 (Hoffner 1998, 62-63).

${ }^{90}$ E.g. CTH 336, Mitos da Deusa Inara, d), $\$ \$ 1-2,2-12$ (Hoffner 1998, 31).

${ }^{91}$ CTH 345, Canto de Ullikummi, $\$ \$ 11-12$, A iii 10-18 (Hoffner 1998, 57-58; para uma tradução diferente García Trabazo 2002, 193-95): «[As...] mulheres fizeram-na dar à luz. As Deusas Destino e as Deusas Mãe [ergueram a criança] e colocaram[-na] nos joelhos de Kumarbi. Kumarbi começou [a divertir-se com] a criança e começou por o limpar(?) e ele deu [à criança(?)] um nome adequado. Kumarbi começou por dizer para si mesmo: "Que nome [hei-de dar] à criança que as Deusas Destino e as Deusas Mãe me deram? Ele saíu do corpo como um eixo. Portanto, que Ullikummi seja o seu nome» (trad. minha). 
deram o filho, mais que a rocha donde saiu Ullikummi. O ato competitório de Kumarbi tem assim sancionamento ou legitimação divina.

A mitologia hurrita concebe o poder também como aliança de várias instâncias. Para além das intervenções de Ea, ora em prol de Tešub, ao enfraquecer Ullikummi ${ }^{92}$, ora ajudando Kumarbi, a libertar-se do sémen de Anu ${ }^{93}$, também o banquete preparado pelo Deus Mar para Kumarbi, no Canto de Ullikummi $i^{94}$, exemplifica o modo como o tema da aliança política preside a boa parte do conflito entre Kumarbi e Tešub. Já o Deus Sol alinha pela facção de Tešub: sendo o primeiro a ver Ullikummi, dirige-se ao rei celeste para lhe dar conta do perigo que se aproxima, após o que Tešub oferece um banquete ao Deus Sol $^{95}$, fazendo do simpósio o momento ideal de realização das alianças políticas.

A guerra promovida por Kumarbi em resultado do seu ressentimento pela perda de poder, implica também uma mediação na luta pelo poder, pois na maior parte do Ciclo de Kumarbi são criados monstros ou deuses para fazer frente a Tešub: Prata, LAMMA, Hedammu e Ullikummi lutam em vez de Kumarbi. Pode ver-se esta situação como paralela ao Mito de Illuyanka, onde também se indicia uma certa mediação na luta pelo poder, pois na primeira versão deste mito o Deus Tempestade é ajudado por Hupašiya. Aliás, a estupidez da serpente, que se deixa enganar pela sua gulodice, surge também como paralela à estupidez de Ullikummi, caracterizado pela cegueira e surdez, uma mais-valia do ponto de vista de Kumarbi, dado que, nessa situação física, não ficaria vulnerável às seduções de Šawoška ${ }^{96}$, as mesmas a que Hुedammu não consegue resistir ${ }^{97}$.

A conceptualização do poder nas narrativas mitológicas hurro-hititas passou ainda pela introdução de uma dimensão temporal alargada, visível não só no facto de o poder ser sucessivamente transmitido durante quatro gerações de deuses, em intervalos de nove anos ${ }^{98}$, mas também na valorização da sageza dos antepassados, como ocorre no Canto de Ullikummi, quando Tašmišu e Tešub procuram Ea com o propósito de conhecer as «palavras antigas», aquelas dos antepassados divinos e que agora se convertem em instrumentos divinatórios necessários para conhecer o ponto fraco de Ullikummi ${ }^{9}$.

A integração da mitologia hurrita também trouxe para solo anatólico uma nova dimensão de encenação literária do poder. Logo na abertura do Canto de Kumarbi, o sentido reverencial do poder surge quase graficamente reproduzido

\footnotetext{
${ }^{92}$ CTH 345, Canto de Ullikummi, $\$ \$ 60-63$, A iii 30-55 (Hoffner 1998, 64).

${ }^{93} \mathrm{CTH} 344$, Canto de Kumarbi, \$ 13, A ii 39-54 (Hoffner 1998, 43).

${ }^{94} \mathrm{CTH} 345$, Canto de Ullikummi, $\$ \$ 6-9$, A ii 1-37 (Hoffner 1998, 57).

${ }^{95} \mathrm{CTH} 345$, Canto de Ullikummi, $\$ \$ 25-31$, A iv 41 - B i 13 (Hoffner 1998, 59-60).

${ }^{96}$ CTH 345, Canto de Ullikummi, $\$ \$ 35-37$, B ii 5-30 (Hoffner 1998, 60-61).

${ }^{97} \mathrm{CTH} 348$, Canto de Hedammu, $\$ \$ 11.1$ - 15.2 (Hoffner 1998, 53-54).

${ }^{98}$ CTH 344, Canto de Kumarbi, $\$ 2$ e ss. (Hoffner 1998, 42 e ss.).

${ }^{99} \mathrm{CTH} 345$, Canto de Ullikummi, $\$ 49$ e ss., A ii 17 e ss. ( Hoffner 1998, 63).
} 
numa cena de serviço ao rei em exercício:

«Há muito tempo, nos primeiros anos, Alalu era rei no céu. Alalu estava sentado no trono e o pesado Anu, o primeiro entre os deuses, permanecia perante ele. Ele inclinava-se aos pés dele (de Alalu) e colocava-lhe na mão taças de bebida.»100

Tal como sucederá quando Anu está no trono e Kumarbi no lugar de Anu' ${ }^{101}$, a hierarquização divina tem aqui um registo literário de verdadeira encenação do movimento das divindades no espaço real, com o ministrum que oferece bebidas ao rei subservientemente inclinado perante ele. Cena similar ocorre no Canto de Ullikummi, quer nas já citadas cenas de banquete entre o Deus Mar e Kumarbi e entre o Deus Sol e Tešub ${ }^{102}$, quer no episódio em que Šawoška e Tešub sobem de mãos dadas ao monte Hुazzi para observar Ullikumi, numa visão que faz Tešub deixar transparecer a sua ira através das feições do rosto ${ }^{103}$. A encenação do sentido reverencial do poder tem ainda um peculiar episódio no Canto de Ullikummi, quando o vizir de Tešub, Tašmišu, beija três vezes os joelhos e quatro vezes os tornozelos de $\mathrm{Ea}^{104}$.

No início do Canto do Deus LAMMA, a encenação do poder evolui mesmo para uma maior dramatização da competição divina, quando LAMMA consegue ferir Šawoška no peito e fazer Tešub cair do céu:

«[...] Enquanto Šawoška falava [com o seu irmão Tešub], a seta de LAMMA [voou] e atravessou(?) Šawoška no peito. Uma segunda seta de LAMMA [voou]. Eles [Tešub e Šawoška] apressaram-se em direção ao carro para [...], [mas a seta de LAMMA] atravessou [...], de tal forma que... não pôde mais... eles não puderam fugir. LAMMA obrigou [...]. Ele tomou [...] e [...] atrás de Tešub. A pedra [foi(?)] atrás de Tešub. Ela bateu no céu e abalou [o céu como se fosse um pano], de tal modo que [Tešub] caiu [do céu]. LAMMA [...] e tomou as rédeas e o [chicote] das mãos de Tešub.» ${ }^{105}$

O registo mitológico hurrita inclui assim uma dimensão dramática da luta divina, similar até a alguns episódios homéricos. Aliás, o poder surge até simbolicamente mediado, no caso pelas «rédeas» e pelo «chicote» de Tešub,

\footnotetext{
${ }^{100}$ CTH 344, Canto de Kumarbi, \$2, A i 5-11 (Hoffner 1998, 42).

${ }^{101}$ CTH 344, Canto de Kumarbi, $\$ 3$, A i 12-17 (Hoffner 1998, 42).

${ }_{102}$ CTH 345, Canto de Ullikummi, $\$ \$ 6-9$, A ii 1-37 e $\$ \$ 25-31$, A iv 41 - B i 13 (Hoffner 1998, 57).

${ }^{103}$ CTH 345, Canto de Ullikummi, $\$ 32$, B i 14-28 (Hoffner 1998, 60).

${ }^{104}$ CTH 345, Canto de Ullikummi, $\$ 52$, A ii 17-12 (Hoffner 1998, 63); dado o estado fragmentário da tabuinha que contêm esta parte do texto, é possível que o autor de tais atos seja Tešub e não Tašmišu.

${ }^{105}$ CTH 343, Canto do Deus LAMMA, § 1-2, A i 2-20 (Hoffner 1998, 46).
} 
demonstrando que a sofisticação narrativa hurrita passou também por uma maior mediação.

A dimensão encenada do poder na mitologia hurrita incluiu também marcas de introspeção, numa verdadeira encenação dos dilemas interiores de exercício do poder, como acontece num dos fragmentos do Canto de Hedammu ${ }^{106}$, mas eleva a encenação literária a um grau superlativo com a introdução de elementos musicais na narrativa, especialmente com a referência aos instrumentos musicais designados por arkammi e galgaturi, cuja natureza exata se desconhece, ainda que parecendo serem de bronze ${ }^{107}$. Aliás, a associação da música ao contrapoder repete-se no Canto de Ullikummi, quando o Deus Mar organiza um banquete para Kumarbi onde estão músicos devidamente equipados com «instrumentos de Ištar» ${ }^{108}$.

A dramatização das narrativas hurritas ganha um fôlego maior com a amplificação da estrutura sentimental dos agentes divinos, atribuindo com frequência registos emocionais humanos às principais divindades. No Canto de Kumarbi, Tešub entristece-se quando sabe da contestação de Kumarbi à sua recém obtida realeza, mas move-se imediatamente para um registo de arrogância, julgando-se superior a todos os deuses, incluindo a $\mathrm{Ea}^{109}$. A emotividade de Tešub tem uma expressão humanizada ainda mais evidente no seu choro, cujas «lágrimas correm como torrentes», após ouvir a descrição de Hुedammu da boca de Šawoška ${ }^{110}$ e depois de saber as novidades acerca de Ullikummi pelo Deus Sol ${ }^{111}$. A humanização do divino tem um desenvolvimento posterior no Canto da Libertação, em que Tešub tem como adversário, não um monstro criado por Kumarbi, mas a sua situação de pobreza e dívidas, ou seja, uma oposição despersonalizada que pode tornar vulnerável até o rei divino em exercício ${ }^{112}$.

Em resumo, relativamente às conceções de poder associadas às narrativas mitológicas hurro-hititas, pode concluir-se que da hurritização resultou a introdução da categoria de realeza no concerto divino, integrada num contexto de

${ }^{106}$ CTH 348, Canto de Hedammu, $\$ 7.1$ (Hoffner 1998, 52-53).

${ }^{107}$ CTH 348, Canto de Hedammu, $\$ 1.1$ (Hoffner 1998, 51): «"[...] [O Deus Mar(?)] ouviu e o seu espírito regozijou-se(?). Ele [apoiou(?)] o seu pé num banco. Eles puseram um ritão na mão do Deus Mar. O grande Deus Mar começou por responder a Kumarbi: "O nosso acordo está estabelecido, Kumarbi, Pai dos deuses. Vem até minha casa dentro de sete dias e [eu dar-te-ei] Šertapšuruhi, minha filha, cujo comprimento é [...] e cuja largura é uma milha. [Tu beberás(?)] Šertapšuruhi como uma doce nata." Quando Kumarbi ouviu (isto), o seu [espírito] regozijou-se. A noite caíu. [...] Eles levaram o grande Deus Mar da casa de Kumarbi acompanhado pela (música dos) brônzeos instrumentos arkammi e galgaturi e acompanharam-no a sua casa. (Aí) ele sentou-se numa boa cadeira feita de [...]. O Deus Mar esperou sete dias por Kumarbi».

${ }^{108}$ CTH 345, Canto de Ullikummi, \$ 8, A ii 14-19, C ii 7-21 (Hoffner 1998, 57).

${ }^{109}$ CTH 344, Canto de Kumarbi, $\$ \$ 18-19$, A iii 2-29 (Hoffner 1998, 44).

${ }^{110}$ CTH 348, Canto de Hedammu, $\$ \$$ 5.1-5.2 (Hoffner 1998, 52).

${ }^{111}$ CTH 345, Canto de Ullikummi, $\$ \$ 30-32$, B i 1-28 (Hoffner 1998. 60).

${ }^{112}$ CTH 789, Canto da Libertação, $\$ \$ 42-46$, ii 4' - 21' (Hoffner 1998, 75). 
rivalidades divinas de base familiar, em que a instituição da paternidade, ou o modelo patriarcal, surge com destacado relevo. Além disso, as estruturas de poder associadas ao mundo divino complexificaram-se, com a inserção de poderes moderadores, conselheiros e sancionatórios, integrados em alianças políticas que associaram a verticalidade do mando à dimensão coletiva do poder, com frequência disputado através de mediadores divinos ou de criações monstruosas. A superlativa encenação do poder, a que se associa o recurso ao símbolo como mediador literário de representação, a par da dramatização das narrativas hurritas, surge como um importante contributo hurrita à mitologia dos Hititas.

\section{Riqueza e complexidade anatólica antiga}

Resta agora discutir se o aporte hurrita à mitologia hitita foi de todo inovador, face à natureza de mitos anatólicos antigos mais complexos como o Desaparecimento do Deus Sol e Telipinu e a Filha do Deus Mar. No primeiro destes dois mitos, o Deus Mar enfrenta o Deus Tempestade através de um processo radicalmente diferente do que ocorre nas narrativas hurritas: o Deus Tempestade enfrenta o problema do desaparecimento do Deus Sol de forma atípica, pela presença de uma força negativa designada pela palavra hitita hahḩima, traduzível para inglês por «Frost $»^{113}$, para castelhano por «Letargo» $»^{114}$, para italiano por «Gelo»" ${ }^{115}$ e para português por «Geada» ou "Gelo»"116.

O mito do Desaparecimento do Deus Sol conceptualiza o poder divino como um combate entre um princípio de vida, concretizado no Deus Tempestade, e um princípio de morte materializado em hahhima, ou seja, tal como sucede nos mitos hurritas, olha-se para o poder divino como resultado de uma oposição, inicialmente caracterizada como rivalidade entre o Deus Mar e o Deus Tempestade. Porém, diferentemente das narrativas mitológicas hurritas, o desígnio deste combate não está na obtenção do lugar cimeiro de rei dos deuses. Parece haver mais semelhanças com o típico mito associado ao ritual mugawar, em que uma divindade desaparece e depois urge encontrar para que a ordem cósmica seja restabelecida, ainda que difira deste tipo de mitos anatólicos antigos pelo facto de o desaparecimento do Deus Sol não ter causa ou origem indeterminada, mas decorrer da disputa entre o Deus Mar e o Deus Tempestade, a fim de se saber qual dos dois é o mais forte ${ }^{117}$.

Ao desaparecimento do Deus Sol segue-se o aparecimento do seu contrário, hahḩ̧ima, uma força paralisante e bloqueadora do crescimento da vegetação que parece pôr em causa o poder do Deus Tempestade, ainda que sem qualquer

\footnotetext{
${ }^{113}$ CTH 323, Desaparecimento do Deus Sol (Hoffner 1998, 27 e ss.).

${ }^{114}$ CTH 323, Desaparecimento do Deus Sol (Bernabé 1987, 62 e ss.)

${ }^{115}$ CTH 323, Desaparecimento do Deus Sol (Pecchioli Daddi-Polvani 1990, 63 e ss).

${ }^{116}$ Galhano 2010, 351.

${ }^{117}$ CTH 323, Desaparecimento do Deus Sol, $\$ \$ 1-2$, A i 1-10 (Hoffner 1998, 27).
} 
disputa por um hipotético lugar de rei divino. A natureza inversa dos efeitos de hahhimima, comparativamente aos efeitos do Deus Sol ${ }^{118}$, fazem dele, mais do que uma força negativa, a ausência de uma força divina positiva, já que ḩaḩhima é o que está quando o Deus Sol não está, ou seja, um negativo do Deus Sol sem estatuto de «deus». Neste aspeto, pode ser encontrada alguma semelhança entre o Mito de Illuyanka e o mito do Desaparecimento do Deus Sol, em virtude de em ambos os textos se tratar de uma luta entre o Deus Tempestade e um princípio de mal, ainda que a serpente do Mito de Illuyanka seja uma força positivamente maligna, ao passo que ḩaḩhima se apresenta como ausência de uma força divina benigna, o Deus Sol.

Para lidar com o problema de ḩahhima, o Deus Tempestade envia consecutivamente outras entidades divinas: o Vento (irmão do Deus Tempestade), o deus da guerra ZA.BA $\cdot \mathrm{BA}_{4}$, o deus LAMMA e finalmente Telipinu (filho do Deus Tempestade), todos derrotados por hahhimima. Na parte final do texto, hoje perdida, supõe-se que, num enfrentamento final protagonizado pelo Deus Tempestade, hahhima fosse finalmente vencido ${ }^{119}$. Também neste aspeto se podem encontrar semelhanças com as narrativas mitológicas hurritas: a mediação na luta pelo poder verificada nas narrativas hurritas (em que Kumarbi se opõe a Tešub por intermédio dos deuses Prata e LAMMA e dos monstros Hedammu e Ullikummi) tem paralelo no facto do Deus Tempestade enfrentar hahhima também através da mediação de outras divindades (Vento, ZA.BA $A_{4} \cdot \mathrm{BA}_{4}, \mathrm{LAMMA} \mathrm{e}$ Telipinu).

Também o Deus Mar luta por intermédio de hahhima, ou seja, de forma igualmente indireta. A mediação na luta pelo poder surge assim como mais um denominador comum às narrativas mitológicas hurritas e ao mito do Desaparecimento do Deus Sol. Pode até ressalvar-se que, na leitura de alguns hititólogos, o real opositor do Deus Tempestade não seria o Deus Mar mas sim o Deus Sol, que se teria ausentado, talvez propositadamente, para testar o poder do seu pai (do Deus Tempestade) através da sua ausência, i.e., da presença de ḩahhhima ${ }^{120}$. Em todo o caso, a oposição ocorre sempre entre dois deuses que se enfrentam por intermédio de outros, divindades ou não.

O Desaparecimento do Deus Sol interessa bastante em razão de nele se cruzarem os dois motivos básicos da mitologia anatólica antiga: o tema da luta do Deus Tempestade com um adversário que, não obstante o sucesso inicial, acaba derrotado, como no Mito de Illuyanka, e o tema da ausência da divindade que provoca o desaparecimento de todos os bens da terra, apenas regressando com a realização de um ritual do tipo mugawar. O facto de, na base do desaparecimento

\footnotetext{
${ }^{118}$ Razão pela qual a tradução para Português poderia ser «Gelo», de forma semelhante à solução de tradução para Italiano.

${ }^{119}$ Cf. Pecchioli Daddi-Polvani 1990, 58-59.

${ }^{120}$ Pecchioli Daddi-Polvani 1990, 60.
} 
do Deus Sol, estar a rivalidade entre o Deus Mar e o Deus Tempestade coloca o mito do Desaparecimento do Deus Sol exatamente na interseção entre os mitos anatólicos antigos e as narrativas mitológicas hurritas.

O paralelo do Desaparecimento do Deus Sol com o Mito de Illuyanka parece contudo ter limites significativos, visto que, se neste último, a luta se dá entre o senhor das águas pluviais (o Deus Tempestade) e o detentor das águas subterrâneas (Illuyanka), no mito do Desaparecimento do Deus Sol, a rivalidade existe entre o Deus Tempestade, enquanto senhor das águas doces, e o soberano das águas salgadas, o Deus Mar, ainda que em ambos os casos vença o detentor das águas mais úteis aos fins agrícolas. Curiosamente, em ambas as narrativas há preocupação em preservar os olhos do Deus Tempestade ${ }^{121}$, instrumento essencial da sua ação. Não obstante, o paralelo do mito do Desaparecimento do Deus Sol com os outros mitos de divindades ausentes parece ser mais significativo do que aquele com o Mito de Illuyanka, até porque em ambos há recurso aos conselhos de Hannahanna ${ }^{122}$.

Por responder fica a questão de saber se foi o mito do Desaparecimento do Deus Sol que, por cisão, deu origem aos temas básicos da mitologia anatólica antiga ou se, inversamente, foram estes temas que, fundindo-se e sofrendo contaminação hurrita, produziram o mito do Desaparecimento do Deus Sol. A intuição diria que a simplicidade (dos temas básicos da mitologia anatólica antiga) terá antecedido a complexidade daquele mito relativo ao Deus Sol, assim se estabelecendo uma hipotética cronologia relativa da mitologia anatólica. O problema torna-se de mais difícil resolução se lembrarmos que a presença de arcaísmos linguísticos e a existência de um fragmento in ductus original em hitita antigo datam o mito do Desaparecimento do Deus Sol de um período bastante recuado na história hitita. O problema complica-se em virtude de, nos mitos de divindades ausentes, os efeitos do desaparecimento da divindade se darem numa realidade socioeconómica mais complexa e estruturada do que no mito do desaparecimento do Deus $\mathrm{Sol}^{123}$, assim se colocando este mito em fase anterior àqueles. Efetivamente, se a maior parte dos mitos de divindades ausentes tem $\mathrm{o}$ seu referente quer no campo, quer nos homens, casas, altares de deuses e recintos de animais, no Desaparecimento do Deus Sol esses referentes estão apenas na realidade agrícola e pastoral.

Para lá das rivalidades divinas presentes no Desaparecimento do Deus Sol, importa saber se aí os poderes estão mais verticalizados, à maneira das narrativas mitológicas hurritas, ou mais horizontalizados, como sucede na generalidade dos mitos de divindades ausentes. A estratégia seguida pelo Deus Mar para

${ }^{121}$ CTH 323, Desaparecimento do Deus Sol, $\$ 7$, B i 32-41 (Hoffner 1998, 28) e CTH 321, Mito de Illuyanka (segunda versão), $\$ \$ 21$ e ss., D iii 2 e ss. (Hoffner 1998, 13).

${ }^{122}$ CTH 323, Desaparecimento do Deus Sol, $\$ 7$, B i 32-41 (Hoffner 1998, 28).

${ }^{123}$ Pecchioli Daddi-Polvani 1990, 61-63. 
enfrentar o Deus Tempestade, como visto, passa pela ocultação do Deus Sol, o que poderia significar que, do ponto de vista do Deus Mar, o Deus Sol seria mais forte e superior do que o seu próprio pai, o Deus Tempestade, assim se configurando uma situação similar ao Canto de Kumarbi, em que as gerações mais jovens de deuses são mais poderosas do que as mais antigas. A parte final do mito, contudo, demonstra que esta perspetiva do Deus Mar é errada, dado que, presumivelmente, o Deus Tempestade acabará por derrotar ḩahhima.

Se o Deus Sol surge em primeiro lugar nas listas de divindades registadas nos tratados hititas ${ }^{124} \mathrm{e}$ se no mito do Desaparecimento de Telipinu ele é apelidado de «grande Deus Sol» ${ }^{25}$, ou mesmo de «Deus Sol dos Deuses» noutros loci ${ }^{126}$, em nenhuma passagem dos mitos anatólicos antigos ele surge qualificado como rei dos deuses, ainda que a função de juiz e de dispensador da justiça que lhe é comummente adstrita o coloque num patamar superior em relação aos humanos e em particular ao rei do Huatti, assim cumprindo a sua função de "pastor da humanidade» por intermédio do rei ${ }^{127}$. Ou seja, a organização do poder no Desaparecimento do Deus Sol assemelha-se mais com a horizontalidade dos mitos de divindades ausentes do que com a rígida verticalidade do mando das narrativas mitológicas hurritas.

A estruturação mitológica em ciclo, visível nas narrativas hurritas, se está praticamente ausente da mitologia anatólica antiga, pode ter ocorrido no Desaparecimento do Deus Sol e no texto Telipinu e a Filha do Deus Mar. A razão de tal possibilidade prende-se com a coincidência de figuras divinas em ambas as narrativas (o Deus Sol, o Deus Tempestade, Telipinu, o Deus Mar e a sua filha) e com o facto de a filha do Deus Mar ser dada como esposa a Telipinu no mito Telipinu e a Filha do Deus Mar e surgir no Desaparecimento do Deus Sol a chamar o seu pai «do céu», para onde teria ido após ser dada como esposa a Telipinu ${ }^{128}$.

O tema deste hipotético ciclo estaria centrado na luta entre o Deus Mar e o Deus Tempestade, em que a refrega entre as duas divindades, no Desaparecimento do Deus Sol, teria tido um prévio episódio de negociação entre o Deus Mar e o Deus Tempestade, cujo mediador eficaz teria sido Telipinu, ao conseguir ganhar uma esposa e fazer com que o Deus Sol regressasse ao seu lugar habitual. A proposta de leitura dos mitos do Desaparecimento do Deus Sol e Telipinu e a

${ }^{124}$ Gurney 1954, 139.

${ }^{125}$ CTH 324, Desaparecimento de Telipinu, $\$ 2$, A i 4-6 (Hoffner 1998, 18).

${ }^{126}$ CTH 671, Sacrifício e Oração ao Deus Tempestade de Nerik, \$9, rev. 11-17 (Hoffner 1998, 24) e CTH 336, Mitos da Deusa Inara, e), $\$ 4$, A rev. 2-5 (Hoffner 1998, 32).

${ }^{127}$ Bryce 2002, 141-42. Šuppiluliuma adotou a titulatura de «Minha majestade, Šuppiluliuma, Grande Rei, Rei do Hatti, Herói...», em que a expressão «Minha Majestade» corresponde ao heterograma ${ }^{\mathrm{d}} \mathrm{UTU}{ }^{\check{I}}$, que contêm o elemento de ligação ao Deus Sol hitita, cujo ideograma era dUTU, assim se evidenciando quer a importância do Deus Sol para o exercício da justiça terrena, quer a quase identificação do rei com aquele deus (Cf. Beckman 2002, 37-41).

${ }^{128}$ Pecchioli Daddi-Polvani 1990, 61-62. 
Filha do Deus Mar como ciclo, que se pode reputar razoável, foi mesmo alargada no sentido de incluir também o mito do Desaparecimento de Telipinu, que daria sequência àqueles dois textos. Esta inclusão, contudo, tem pouca sustentação, dado que, neste último, a divindade não desaparece em consequência de alguma luta divina, como ocorre no Desaparecimento do Deus Sol e em Telipinu e a Filha do Deus Mar, mas antes por motivos imprevistos e desconhecidos que não são sequer relacionáveis com alguma falta humana ${ }^{129}$.

Em todo o caso, a fixação da trama inicial do mito Telipinu e a Filha do Deus Mar na tensão entre dois deuses - o Deus Tempestade e o Deus Mar -, ainda que possa ser mera reflexão mitológica sobre fenómenos naturais, aproxima também este mito das narrativas hurritas, cujo tema principal está na disputa entre Kumarbi e Tešub, ainda que naquele mito sem quaisquer preocupações pela realeza divina. Verifica-se ainda outra analogia do mito Telipinu e a Filha do Deus Mar com as narrativas mitológicas hurritas, relativa à instância do poder conselheiro: se nas narrativas hurritas essa instância surge concretizada, por exemplo, em Šerrišu e Tašmišu, que aconselham Tešub, no mito Telipinu e a Filha do Deus Mar, é Hennahanna quem intervém para dar conselhos ao Deus Tempestade, relativos ao pagamento do dote ao Deus Mar ${ }^{130}$. A caracterização de Hannahanna como um poder conselheiro no mito Telipinu e a Filha do Deus Mar tem confirmação no Desaparecimento do Deus Sol, em que o Deus Tempestade, após ver frustradas todas as tentativas de derrotar o Deus Mar através de terceiros, decide procurar justamente Hुannahanna.

O facto de o Deus Mar entregar a sua filha a Telipinu, juntamente com a libertação do Deus Sol, pode revelar uma estratégia de aproximação do Deus Mar ao Deus Tempestade, ou seja, o Deus Mar pode ter usado o casamento de sua filha como estratégia de obtenção de poder, assim se aproximando da divindade que ele próprio qualifica de poderosa. Esta leitura aproxima o mito Telipinu e a Filha do Deus Mar da segunda versão do Mito de Illuyanka, em que também o casamento serve de expediente para a obtenção de poder, no caso, o casamento do filho do Deus Tempestade com a filha de Illuyanka, com o objetivo de reaver os olhos e o coração perdidos no primeiro combate com a serpente.

Finalmente, em abono da riqueza da mitologia anatólica antiga, seguramente comparável à fertilidade de conceções mitológicas de poder das narrativas hurritas, pode ainda ver-se que a ação maléfica de hahhima, no Desaparecimento do Deus Sol, tem um episódio similar no mito O Conjuro da Atadura, em que também a força maléfica Grande Rio surge como agente principal das complicações sofridas quer no mundo agrícola e pastoral, quer na esfera humana, com a

\footnotetext{
${ }^{129}$ Galhano 2010, 349-58.

${ }^{130}$ CTH 322, Telipinu e a Filha do Deus Mar, $\$ \$ 5-6$, A ii 6-25 (Hoffner 1998, 26-27).
} 
particularidade de, neste mito, também o Deus Tempestade participar na ação maléfica que prejudica, não só homens e animais, mas também a divindade LAMMA $^{131}$.

\section{CONSIDERAÇÕES FINAIS}

A hurritização étnica do território hitita derivou de um longo processo de contactos populacionais entre Hititas e Hurritas, tendo início bem cedo na história da Anatólia. A guerra e a política expansionista dos Hititas foram dos principais agentes propiciadores deste intercâmbio étnico, ainda que a hurritização populacional da Anatólia também tenha ocorrido em tempo de paz entre Hattuša e o Mitanni. A ingerência egípcia no norte da Síria, designadamente com o estabelecimento do acordo mitano-egípcio no reinado de Arnuwanda, reforçou a presença hurrita nas fronteiras do reino hitita, preparando a substanciação do perfil hurro-hitita da cultura anatólica no tempo de Šuppiluliuma I. As instituições políticas imperiais, mormente a vice-realeza, promoveram ainda mais essa condicionada fusão cultural entre Hurritas e Hititas. Desta perspetiva, deve valorizar-se o papel de elementos como Puduhepa na amalgamação cultural dos setores hurrita e hitita, desembocando mais tarde, já com Tudhaliya IV, no símbolo da hurritização religiosa hitita por excelência: os relevos de Yazılıkaya.

Vimos que, nos mitos anatólicos de divindades ausentes, exceção feita ao mito do Desaparecimento do Deus Sol e a outros mitos menores, sobressaem conceções de interdependência e correlação divina, alinhadas pelo diapasão da necessidade de harmonia celeste para o bom andamento da ordem cósmica, ainda que estes primeiros mitos da Anatólia estejam ligados a rituais destinados a superar momentos de crise. A tendência não hierárquica dos mitos anatólicos antigos, se também assume registos de complementaridade no reconhecimento de pares divinos, como é exemplo a dupla formada pelo Deus Tempestade e pela Deusa Sol, chega a associar uma certa pusilanimidade a alguns agentes divinos. Em todo o caso, alguns deuses do panteão autóctone da Anatólia parecem ter algum ascendente sobre outras divindades, como acontece exemplarmente com Hannahanna.

A tendência não hierárquica dos mitos anatólicos antigos de divindades ausentes dissipa-se no seu quase contemporâneo Mito de Illuyanka ${ }^{132}$, onde se observa uma modalidade de luta do Deus Tempestade com uma força má genericamente designada «serpente». Aí, a luta pelo poder simboliza a vitória do bem sobre o mal, mas também a competição pelo domínio das águas subterrâneas

${ }^{131}$ CTH 390, O Conjuro da Atadura (Bernabé 1987, 86-87).

${ }^{132}$ Cf. Galhano 2010, 349-58, onde se argumenta pela posteridade do Mito de Illuyanka em relação aos mitos de divindades ausentes, fundamentando-se tal proposta no facto de, no Mito de Illuyanka, haver uma conceção teodiceica inexistente nos mitos de divindades ausentes. 
e das águas pluviais, reconhecendo-se a superior valia das segundas para fins agrícolas. O Mito de Illuyanka ostenta uma estória de recuperação de poder perdido por parte do Deus Tempestade que, aquando da sua primeira derrota, é abandonado pelo coletivo divino, apenas recuperando a sua reputação depois de um segundo combate com a serpente. Tal aspeto demonstra que a solidariedade divina dos mitos de divindades ausentes está ali desaparecida.

Com a adoção das narrativas mitológicas hurritas, cujo aporte maior se concretizou no Ciclo de Kumarbi, é introduzida a ideia de realeza divina disputada em sucessivas conjunturas geracionais. Uma vez Tešub nomeado rei divino, o Ciclo de Kumarbi desenvolve o ressentimento de Kumarbi por ter sido destronado. O poder surge aí integrado em duas linhagens familiares de divindades, cada uma delas associada ou ao domínio celeste ou ao mundo inferior, sendo possível que esta base familiar da disputa possa ter tido um referente arcaico em mitos que reviviam e ritualizavam a oposição entre as forças do mundo inferior e potências de ordem celeste. Assim, as narrativas mitológicas hurritas adotadas pelos Hititas valorizam o horizonte familiar. A belicosidade associada às narrativas mitológicas hurritas, se pode ser considerada um reflexo do contexto político hurrita, em permanente tensão com Hattuša, tem também fortes possibilidades de consubstanciar uma forma narrativa de registo do traumático, coisa que não acontece nem no Mito de Illuyanka, nem nos mitos de divindades ausentes (exceção feita ao mito do Desaparecimento do Deus Sol), que na sua essência tendem a valorizar a superação da crise e a vitória das forças celestes favoráveis à agricultura.

A complexificação que resultou da integração do Ciclo de Kumarbi no Hatti, traduziu-se na adoção de diferentes instâncias de poder. Dentre as mais importantes, destacámos não só a instância do poder moderador e legitimante, concretizado no deus Ea, mas também os níveis de poder conselheiro, encorpados tanto em Šerrišu como nos vizires do poder e do contrapoder, factos que permitiram estabelecer um paralelo com a conceção de poder associada à deusa Hannahanna dos mitos de divindades ausentes. Aquela instância do poder conselheiro deriva em poder sancionatório das Deusas Destino e das Deusas Mãe junto de Kumarbi, especialmente no momento de criação de Ullikummi. Em todo o caso, a ideia de aliança de várias instâncias de poder subjaz a toda a mitologia do Ciclo de Kumarbi. A mitologia de origem hurrita encena assim uma conceção de poder divino coletivo, ainda que bastante hierarquizado e multi-estruturado. O ressentimento de Kumarbi, ao resultar na criação de monstros maléficos e de divindades concorrentes de Tešub, demonstrou ainda que as narrativas do Ciclo de Kumarbi conceptualizaram as lutas pelo mando como uma ação mediada do opositor ao poder.

A multi-estruturação do poder nas narrativas de origem hurrita incluiu ainda a introdução de uma dimensão temporal alargada. Esta conceptualização dos governos divinos foi também acompanhada de uma nova dimensão 
literária do poder, em diversas ocasiões representada de forma extremamente gráfica. A encenação literária levada a cabo nas narrativas mitológicas hurritas ganhou uma dramatização da competição divina ainda maior através da fixação de cenas de pungente belicosidade divina e com a adoção literária de símbolos do poder. Esta encenação literária, sem paralelo na mitologia anatólica antiga, incluiu mesmo registos de introspeção divina, trazendo os dilemas interiores do exercício do poder para o nível mitológico. No Ciclo de Kumarbi, há ainda um adicional registo dramático com a introdução de elementos musicais e com a estruturação sentimental dos deuses em tons frequentemente humanizados.

Não obstante a variedade das conceções de poder visíveis nas narrativas mitológicas hurritas, alguns mitos anatólicos antigos mostram também uma extraordinária riqueza e complexidade conceptual. A luta entre deuses tem registo quer no mito do Desaparecimento do Deus Sol quer no texto Telipinu e a Filha do Deus Mar, ainda que sem recurso à categoria hurrita de rei divino. Esta competição apresenta semelhanças com o Mito de Illuyanka, pelo facto de também nos mitos do Desaparecimento do Deus Sol e Telipinu e a Filha do Deus Mar haver uma oposição entre o Deus Tempestade e um princípio de mal, concretizado em hahhinima.

As conceções de poder no mito do Desaparecimento do Deus Sol são comparáveis aos registos das narrativas hurritas em virtude de em ambos os casos a competição divina ocorrer através da mediação de outros agentes rivais dirigidos pelos oponentes principais. O mito do Desaparecimento do Deus Sol está mesmo na exata interseção conceptual dos mitos anatólicos antigos com as narrativas hurritas, visto cruzar os temas da ausência divina, típica dos mitos de divindades ausentes, e da luta de um deus com uma força má, característica do Mito de Illuyanka, com a conceptualização do poder em rivalidade, essencial ao Ciclo de Kumarbi.

Não se podendo saber se foi o mito O Desaparecimento do Deus Sol que, por cisão, originou os temas mais elementares da mitologia anatólica antiga - a ausência divina e a oposição entre o Deus Tempestade e uma força má - ou se, inversamente, foram esses temas que se fundiram e deram origem àquele mito, posteriormente enriquecido com o tema hurrita da rivalidade divina, não se pode estabelecer com segurança uma cronologia relativa da mitologia hurro-hitita. Contudo, pode afirmar-se que a estruturação do poder no Desaparecimento do Deus Sol assemelha-se mais com a horizontalidade da generalidade dos mitos anatólicos antigos do que com a verticalidade do poder das narrativas do Ciclo de Kumarbi. A estruturação narrativa em ciclo visível no Ciclo de Kumarbi pode também ter tido paralelo na mitologia anatólica antiga, dado que o mito do Desaparecimento do Deus Sol pode ser a consequência diegética de Telipinu e a Filha do Deus Mar. O texto Telipinu e a Filha do Deus Mar contém também outros ingredientes comuns ao Ciclo de Kumarbi, designadamente a 
conceptualização de poderes conselheiros na orquestra divina.

Em suma, se a hurritização dos conteúdos mitológicos trouxe para solo anatólico novas estruturas de sentido assentes em novas conceções de poder, a mitologia anatólica antiga continha já uma grande diversidade de ingredientes conceptuais, razão pela qual não exageramos o valor do aporte hurrita às conceções de poder da mitologia anatólica mais antiga. 


\section{BibliografiA}

Barjamovic, Gojko. 2011. A Historical Geography of Anatolia in the Old Assyrian Period. Copenhagen: Museum Tusculanum Press.

Beckman, Gary. 2007. "From Hattuša to Carchemish: The Latest on Hittite History." In: Current Issues and the Study of the Ancient Near East, ed. Mark W. Chavalas. Claremont, California: Regina Books.

—_. 2002. "'My Sun-God': Reflections of Mesopotamian Conceptions of Kingship among the Hittites." In Ideologies as Intercultural Phenomena, Proceedings of the Third Annual Symposium of the Assyrian and Babylonian Intellectual Heritage Project Held in Chicago, USA, October 27-31, 2000, ed. A. Panaino e G. Pettinato, 37-43. Milano: Università di Bologna.

Beckman, Gary e Harry Hoffner, eds. 1999. Hittite Diplomatic Texts. $2^{a}$ ed. Atlanta, Georgia: Scholars Press / Society of Biblical Literature.

Bernabé, Alberto. 1987. Textos Literarios Hetitas. Madrid: Alianza Editorial.

Bíblia Sagrada. 1995. Lisboa: Difusora Bíblica.

Bryce, Trevor. 2005. The Kingdom of the Hittites. Oxford: Oxford University Press. —2002. Life and Society in the Hittite World. Oxford: Oxford University Press.

Carreira, José Nunes. 2009. Mitos e Lendas Hititas. Lisboa: Colibri.

—_ 1999. Historiografia Hitita. Lisboa: Colibri / Centro de História da Universidade de Lisboa.

Collins, Billie Jean. 2007. The Hittites and their World. Atlanta: Society of Biblical Literature.

Dietrich, Manfried, Oswald Loretz e Joaquín Sanmartín, eds. 1995. The Cuneiform Alphabetic Texts: from Ugarit, Ras Ibn Hani and other places $(K T U)$. Münster: Ugarit-Verlag.

Eder, W. e J. Renger, eds. 2007. Chronologies of the Ancient World, Names, Dates and Dynasties. Leiden / Boston: Brill.

Ferro, Marc. 2009. O Ressentimento na História. Lisboa: Editorial Teorema.

Friedrich, Johannes. 1991. Kurzgefaßtes Hethitisches Wörterbuch. Heidelberg: Carl Winter - Universitätsverlag.

Galhano, João Paulo. 2012. Espaço, Tempo e Poder nos Mitos do Hatti, de Ugarit e de Hesíodo, Uma Morfologia Comparativa. Dissertação de Mestrado em História Antiga apresentada à Universidade de Lisboa.

___ "Representações e usos humanos nos mitos anatólicos antigos." Cadmo 20:347-67.

García Trabazo, José Virgilio. 2002. Textos Religiosos Hititas: Mitos, Plegarias y Rituales. Madrid: Trotta. 
Gurney, O. R. 1954. The Hittites. Harmondsworth: Penguin Books.

Güterbock, Hans G., H. Hoffner Jr. e Theo van den Hout. 2002-2013. The Hittite Dictionary of the Oriental Institute of the University of Chicago. Vol. Š, Fascicles 1, 2 e 3. Chicago: The Oriental Institute.

- 1997. The Hittite Dictionary of the Oriental Institute of the University of Chicago. Vol. P. Chicago: The Oriental Institute.

-1989. The Hittite Dictionary of the Oriental Institute of the University of Chicago. Vol. L-N. Chicago: Oriental Institute.

Hoffner, Harry. 2009. Letters from the Hittite Kingdom. Atlanta: Society of Biblical Literature.

—_ 1998. Hittite Myths. 2a ed. Atlanta, Georgia: Scholar Press.

Klengel, Horst. 1998. Geschichte des hethitischen Reiches. Leiden: Brill.

Laroche, Emmanuel. 1971. Catalogue des Textes Hittites, Études et Commentaires. Paris: Klincksieck.

Larsen, Mogens Trolle. 2015. Ancient Kanesh: A Merchant Colony in Bronze Age Anatolia. Cambridge: Cambridge University Press.

Liverani, Mario. 2001. International Relations in the Ancient Near East, 1600 1100 BC, New York - Basingstoke.

MacQueen, J. G. 1959. "Hattian Mythology and Hittite Monarchy." Anatolian Studies 9:171-88.

Neu, Erich, ed., trad. e comentário. 1996. Das hurritische Epos der Freilassung I, Untersuchungen zu einem hurritisch-hethitischen Textensemble aus Hattuša. Wiesbaden: Harrassowitz Verlag.

Olmo Lete, G. del. 1981. Mitos y Leyendas de Canaan, Segun la Tradicion de Ugarit. Madrid: Ediciones Cristiandad.

Pecchioli Daddi, Franca e Anna Maria Polvani. 1990. La Mitologia Ittita. Brescia: Paideia Editrice.

Pritchard, J. B., ed. 1969. Ancient Near Eastern Texts Relating to the Old Testament. $3^{\mathrm{a}}$ ed. Princeton, New Jersey: Princeton University Press.

Rieken, E., Daniel Schwemer, Gerfrid Müller, Doris Prechel e Gernot Wilhelm, dir. 2009-. Mythen der Hethiter in Hethitologie Portal Mainz. Em https:// www.hethport.uni-wuerzburg.de.

Watkins, Calvert. 2001. "An Indo-European linguistic area and its characteristics: Ancient Anatolia." In Areal Diffusion and Genetic Inheritance, ed. P. Aikhenvald e R. Dixon, 44-63. Oxford: Oxford University Press.

Wegner, Ilse. 2007. Einführung in die hurritisch Sprache, 2., überarbeite Auflage. Wiesbaden: Harrassowitz Verlag.

Yigit, Turgut. 2016. "The political and cultural meanings of the Hittite empire period rock monuments." Athens Journal of History 2 (1):59-67. 